Article

\title{
Italian Rationalist Design: Modernity between Tradition and Innovation
}

\author{
Federica Dal Falco
}

Department of Planning Design Architecture Technology, Sapienza University of Rome, 00196 Rome, Italy; federica.dalfalco@uniroma1.it

Received: 7 January 2019; Accepted: 15 February 2019; Published: 22 February 2019

\begin{abstract}
This article is devoted to the Italian modern project of the 1930s, which involved architecture and design. The main theme is the influence that the autarchic economic policy of the Fascist regime had in the choice of materials and technologies, and, above all, the manner in which this choice led to innovative practices and figurative research. Through significant examples, the essay provides some insight into the style of Italian rationalism, whose contradictory aspects-conditioned by the regime's policy—shaped urban planning, architecture, and design in the 1930s. I show that the Italian rationalist culture is a field of investigation that is of considerable scientific interest because it represents the idea of an integral project comprised of all the elements associated to a building, including those that are still used today. In particular, I present a case study centered on the Physics Institute of Rome's Sapienza University (1933-1935) designed by the architect Giuseppe Pagano Pogatschnig, analyzing its materials, technologies, and architectural features, as well as its furnishings. Along these lines, the objective of this investigation is the transmission of a specific knowledge, looking at objects as essential parts of the aesthetics of Rationalism in order to protect and enhance the cultural heritage of modernity.
\end{abstract}

Keywords: rationalism; modern architecture and design; autarchic materials and technologies

\section{Introduction}

The essay outlines the frame of a particular period in the modern history of Italian architecture and design, highlighting the modalities whereby technologies and new materials conditioned the figurative and constructive research of that period.

The question is naturally linked to the Italian political, economic, and social events that, from the early twenties of the twentieth century to the end of the Second World War, have influenced all aspects of any project-architectures, furnishings, objects, and even fashion (Finessi 2014). The knowledge of the autarchic production is necessary because, in addition to being fundamental in the maintenance choices, the restoration of buildings, and the redevelopment of sites, it concerns an important and conspicuous system of objects and furnishings that, as testimonies of the value of civilization, participate in the enhancement of the Italian cultural heritage (Dal Falco 2014, pp. 7-13). Stone cladding, aluminum alloys, reconstituted wood, and glasses manufactured by strictly national enterprises were utilized to build public and private buildings and to make interior and exterior furniture.

Therefore, this article focuses on the modalities whereby the autarchic phenomenon manifested itself in architecture and design, analyzing the most relevant production of traditional and innovative materials obtained by exploiting local resources (Poretti and Vittorini 1996).

The knowledge and the arguments that this article is based on refer to a number of scientific publications undertaken since the end of the seventies by academicians and scholars (Danesi and Patetta 1976; Mantero 1984; Poretti 1990; Poretti 2013) and to research and activities promoted by international associations such as Docomomo International and Docomomo Italia. In the space of 
approximately thirty years, research aimed at improving the knowledge and the preservation of Italian architecture of the interwar period produced many scientific publications with disciplinary insights on the "restoration of the modern" and some exemplary interventions that have become international benchmarks (Poretti 2005).

In the field of design, there were some excellent contributions to the study of Italian design of the period (De Fusco 2010; Finessi 2014; Gregotti 1982; Tonelli-Michail 1987; Polin and Selvafolta 1988). Moreover, relevant research has been conducted on the interior design of modernity (Sparke 2008) and on the Italian design from the postwar period to the postmodernist movement, emphasizing a craft approach (Rossi 2015).

Sparke's book is exemplary for its reconstruction of modern society through interiors. The interior design of modernity is not outlined by focusing on objects, but "by its relationship with the everyday experiences of modernity during those years, which were as profound in the office, the factory, the department store and the café-as well as in the modern hospital and church—as they were in the home" (Sparke 2008, p. 7).

Catharine Rossi examines the multiple ways whereby craft shaped Italian design from 1945 to 1981 in the context of the socio-economic, cultural, and political changes of the period. Rossi's book is a paradigm for the use of craft-based approaches and for the study of design and craft's relationship in other periods, cultures, and contexts.

My article builds on these methodologies and significant scientific contributions by reconstructing the historical scenario in which the Italian rationalism developed and by analyzing some important examples of architecture and design with special attention given to the influence of autarchy on them.

Hence, its peculiar contribution lies in the recognition of the values and meanings of the materials and elements of design. In the Italian interwar context, this analysis is particularly useful for a better understanding of three related issues-the extent to which autarchic policy and production conditioned Italian architecture and design, the search for an Italian specific modernity that finds, in the design, a space of experimentation freer, lighter, and more linked to contemporary international experiences, and the role of the integral architect, who was fully involved in the design of objects reproducible in series.

As mentioned above, in the field of architecture, the "restoration of the modern" is a discipline recognized internationally. It was only recently that some studies dealt with the preservation of furnishings and objects in their entirety (Abram 2014). In general, research activities on architecture and design have been undertaken separately, while my article is based on the idea that research on buildings and furnishings of Rationalism, consistent with the integrated method underlying their conception and realization, should be conducted according to a unitary approach in order to reconstruct their original framework at any scale.

Hence, the value this article adds relative to the existing literature on the matter is two-fold-it analyzes the influence of the autarchic economic policy on production in the construction sector and in the design components, and it shows that, relative to the productive context and the professional profile of the Italian architects of those years, the furnishings and the objects of rationalist buildings were parts of an integrated conception. Thus, theories and best practices concerning the regeneration and the restoration of rationalist architecture should approach the architectural organism in its entirety, assigning the same value to the objects as to the buildings.

In Section 2, I briefly outline the politico-economic context with a synthesis of the production of autarchic materials and technologies and an overview of the ideological influence of the regime on Italian rationalism. Through some examples, I demonstrate how the response of young Italian architects was open to the principles of contemporary international architecture. Section 2.3 is devoted to analyzing main architectural themes that emerge from the comparison of buildings, such as the use of marbles and stones for exterior and interior cladding, the relationship between the structure and the façade, the new flat roofs (often walkable) used as a solarium or as skylights, and the design of window frames in iron or aluminum alloys that are results of innovative patents. Section 2.4 is focused 
on design, with some examples of Italian furnishings designed by the architects of rationalism for the interiors of their buildings and manufactured by Italian companies. In particular, I describe the tubular metal types that were inspired by the Bauhaus models and in general by the German production of the period (Pansera 1998).

In Section 3, I present a case of global rationalist project, the campus of the Sapienza University of Rome (1933-1936), with an in-depth analysis of the Institute of Physics designed in all its elements by the architect Giuseppe Pagano Pogatschnig (1896-1945).

In the Conclusions, consistently with the viewpoint developed in the previous sections, I make some points regarding the protection and enhancement of the cultural heritage of Modernity in its entirety, considering architectures and furnishings as intrinsically interconnected.

\section{The Political Economic Context and Its Influence on the Rationalism between Tradition and Innovation}

\subsection{The Political Economic Context and the Autarkic Production for Architecture and Design}

In order to understand the Italian context of those years and the evolution of the autarchic economic policy, it is important to remember that the autarchic phenomenon began in the early $1920 \mathrm{~s}$ and developed gradually (Giardina et al. 1988).

The year that marked the seriousness of the economic crisis that had broken out two years earlier was 1931. The theme of the relaunch of the internal market took a leading role, and the development of scientific research on advanced technologies became a primary importance. In Italy, for this purpose, the CNR (National Research Council) was founded under the direction of the inventor Guglielmo Marconi (1).

Afterwards, with the worsening of the economic crisis, international trade weakened. Beginning in 1933, the nationalist perspective strengthened and the autarchic process was subject to a strong acceleration (Maiocchi 2013). Benito Mussolini assumed de facto dictatorial powers in January 1925 and, in view of the war, traced the definitive stance of the economic policy providing the maximum exploitation of the national resources and a strict corporatist organization (Mussolini 1957). The construction of the Italian Empire began to take place with the war of Ethiopia (1935-1936) and became the dominant element of Italian politics. In October 1935, the League of Nations deliberated economic sanctions against Italy, which were implemented in November. The embargo concerned arms and ammunition, the system of loans and credits, and the import and export of goods necessary for the war industry in Italy. These limitations forced Italy to concretely realize autarky, and the construction sector was one of the most involved production areas. In 1937, autarky assumed the characteristics of a concrete plan, consisting of a set of coordinated measures whose development was expected to unfold over a long period (Anselmi et al. 1938). First of all, the scheme contemplated a set of synergic actions focused on production applied to key industries (metallic minerals, textiles, solid and liquid fuels) and on consumption associated with the fight against waste. These actions were integrated by exploiting all the possibilities of replacing products whose raw materials were scarce or not present on Italian soil (Maiocchi 2013; Dal Falco 2013, pp. 68-77).

The collapse of the scrap iron import, fundamental for the steel industries, posed the problem of replacing metal materials with the consequent abrupt arrest of the construction sector. In order to relaunch the construction industry, autarchic methods were studied, which included lightening the weight of buildings by replacing traditional masonry with insulating materials. Naturally, these products were linked to the spread of reinforced concrete and iron structures-a great technical innovation that marked the architectural research of the modern and of the Italian architecture of the period (Ascione 2017, p. 330).

Insulating materials were cheap products characterized by high performance. Italian products referred to German, French, and American patents, and were distinguished by their constituent elements, production techniques, and uses. The Eraclit, the Populit, and the Carpilite were made of wool and vegetable residue conglomerates impregnated with magnesite and hardened with concrete. 
Other groups were those of wood fiber derivatives such as Masonite and Cel-bes, of cork such as Absorbite and Asphalted Cork, or products that used wheat or rice straw stalks compressed and bound with iron wire such as Solomit, licorice roots (Maftex), or sugar cane fibers (Celotex) (Cupelloni 2017, pp. 328-29). The pumice stone-present on Lipari island-was used in concrete conglomerates. Then, instead of the reinforcing steel used for pillars and beams, bamboo elements or aluminum bars were tested (Maiocchi 2013).

The buildings' external cladding played an important role in the construction industry autarky. The use of stone materials, widely present on Italian soil, was strongly supported by autarchic propaganda (Dal Falco 2017, pp. 86-87). Marbles, stones, and granites were especially recommended for public works in order to reinforce the solidity and monumentality of buildings (Poretti 1990).

The use of reinforced concrete and steel skeletons resulted in a drastic reduction of the load-bearing walls. Stones and bricks continued to be utilized to build structures, although the autarchic limitations forbade the reinforced concrete for buildings over five floors (Cupelloni 2017, p. 28).

In the pillar-pillar plugging, solid bricks were replaced by perforated bricks, and the construction of brick walls with interposed inner tube became a common practice. The Litoceramica, which simulates the size and the appearance of the brick, is a new material for exterior cladding, and it has a color palette ranging from dark red to yellow-grey. Hard and compact, the Litoceramica was produced by the company S.A. Ceramica Piccinelli from Bergamo and was widely used in public works, as for the Città Universitaria (1933-1935) in Rome (Bernardini 2017, pp. 146-50) (Figure 1).

The import restrictions, the national resources exploitation, and the fight against waste favored the use of wood processing derivatives with the aim of producing practical and cheap coatings (Faesite, Masonite, Insulite, Buxus) as replacements for traditional materials. In fact, this product category presented all the characteristics of the regime propaganda that combined the autarchic appeals with an emphasis for the new. The Faesite was obtained by recycling the sawmill residues and was produced in five types from extra-porous to extra-hard. An interesting Faesite application was the realization of removable and interchangeable partition walls that divided office rooms (Dal Falco 2002, pp. 257-89) in the office buildings of Montecatini (Milan, 1936-1938) by Gio Ponti (1891-1979). Similarly, the Masonite was a reconstituted wood obtained from the manufacturing of waste wood materials. This product was used to make some elements of the Rent House in Cernobbio (1938-1939) by Cesare Cattaneo (1912-1943) (Figure 2). It is a small and complex building characterized by a concept of poly-dimensionality evident in the façade design where the ground floor, the overhangs of the balconies, and the last floor are balanced. The natural Masonite was used to cover the internal doors and the external windows doors set back from the perspective line (Dal Falco 2002, pp. 365-81).

In the context of a modernity global design and in respect of autarchic indications, Buxus and linoleum exemplify the trait d'union between architecture, interior, and furniture design.

The Buxus was produced by Giacomo Bosso paper mills in three types-the "concia molle" type used to coat boxes and suitcases, the "semi-rigid" type for furniture veneering, and the "thin" type to cover walls replacing the upholstery. For its flexibility, solidity, chromatic qualities, and the surface marble veins, the Buxus was considered a product between craftsmanship and industry (Garda 2017, pp. 346-47; Pagano Pogatschnig 1934, p. 48).

The architects Gino Levi Montalcini and Giuseppe Pagano Pogatschnig, pursuing a global approach, designed the Palazzo Gualino office buildings, the interiors, and the furniture (Turin, 1928-1930) (Figure 3). The 67 kinds of furniture (tables, chairs, small armchairs, shelves, drawers) were simple and squared, and they were all made using a fir structure and a plywood layer on which the Buxus veneer was applied and then finished with a nitrocellulose spray paint (Chessa 1930, p. 21; Capitanucci 2017, pp. 350-51).

The Buxus was well suited to the modernity compositional principles-the absence of decorative elements, right angles, smooth surfaces, pure volume-and to the space's geometric design where the furniture was an integral part. The furnishings were manufactured by the F.I.P. (Fabbrica Italiana Pianoforti) specialized in the pianos realization and active in Turin since 1917. In 1927, the company 
was acquired by Riccardo Gualino, who expanded the production to the office furniture sector in conjunction with the Palazzo Gualino construction (Castagno 1994, p. 54) (Figure 4).

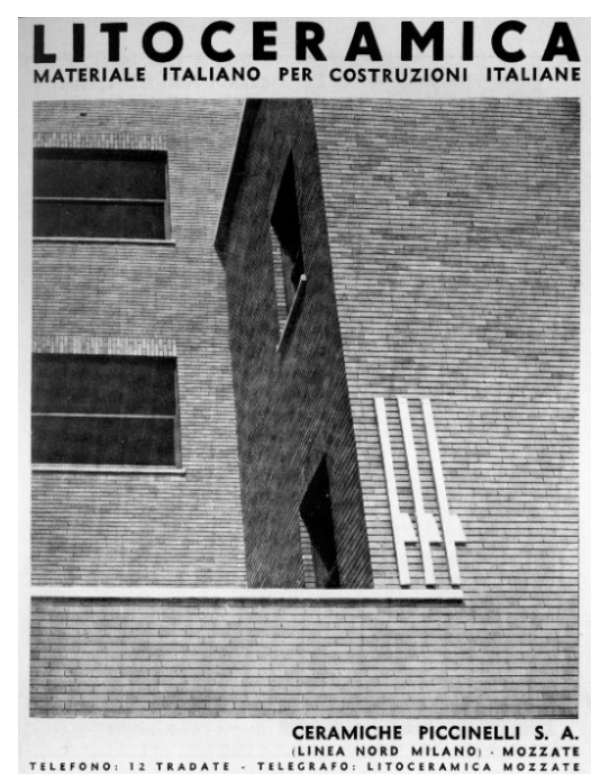

Figure 1. Litoceramica Piccinelli advertising. Photo from (Baliviera et al. 1935).

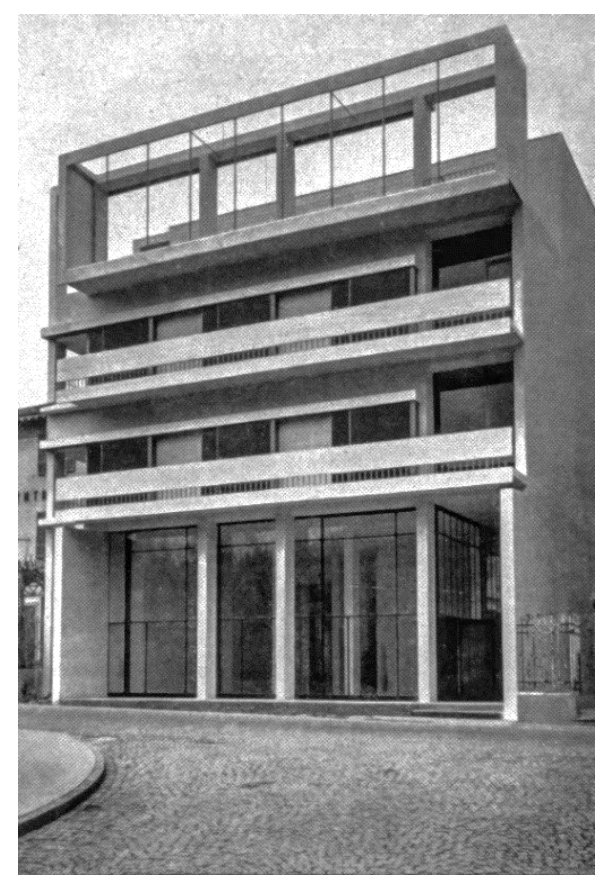

Figure 2. Rent House in Cernobbio of Cesare Cattaneo (1938-1939). Photo from (Sartoris 1957, p. 272).

The linoleum was mainly composed of linseed oil, which was subsequently transformed into a thin coating and then laminated on jute sheets. Patented by Frederick Walton in 1863, linoleum was produced in Italy by the Società del Linoleum of Milan. It was proposed in different models for color and pattern among which were stone, wood, and marble imitations. Linoleum was supported by articles (Marescotti 1937), advertising, and project publications from the quarterly magazine Modern Building-Linoleum Magazine, founded in 1929.

Due to its aesthetic, chromatic, and hygienic qualities, it has been one of the most appreciated and used materials for both domestic and public environments. 
The floorings in homes, offices, hospitals, schools, universities, marine and mountain colonies, and representative buildings were in linoleum; they were classic with stone imitation design and "modern" with geometric surfaces and solid colors (Bosia 2017, pp. 368-69).

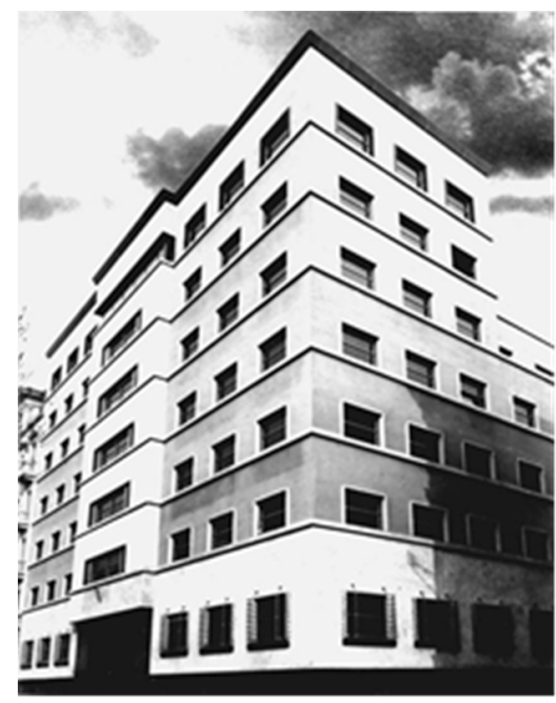

Figure 3. Palazzo Gualino offices of Giuseppe Pagano Pogatschnig and Gino Levi Montalcini. Turin (1928-1930). Photo from (Danesi and Patetta 1976).

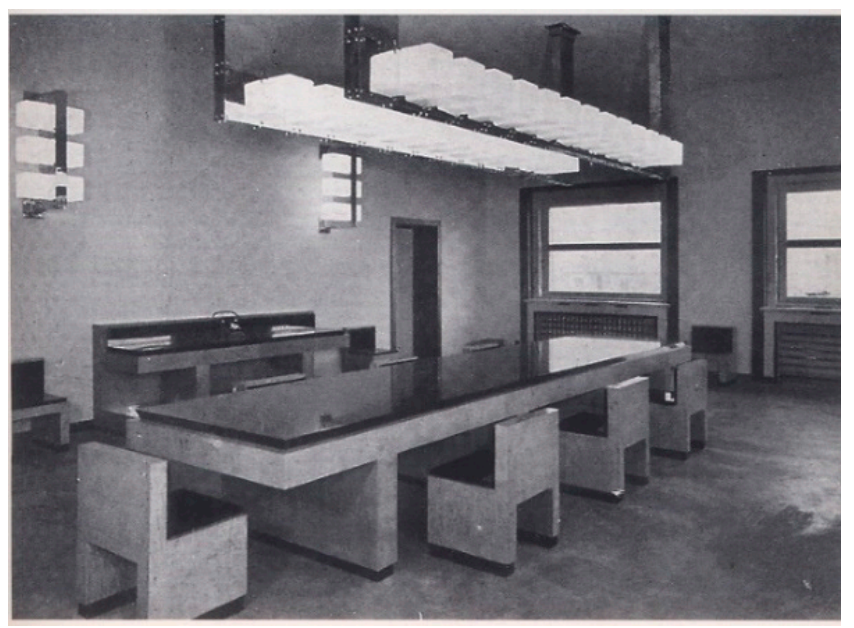

Figure 4. Palazzo Gualino offices. Meeting room. Furnishings in Buxus. Photo from (Ponti 1930).

The linoleum allowed for continuous floorings, which enhanced the linearity and the geometries of rational environments and the furniture surfaces and interiors (Dal Falco 2014, p. 25) (Figure 5). Finally, there are white metals and glass products, which played a major role in the most advanced figurative and constructive experimentation of architecture and rationalist design.

Initially, aluminum had a fundamental importance in aeronautics but also became essential in other productive sectors including window frames, handles and balustrades, household objects (pots, cutlery), and furniture structures (Figure 6).

This material was obtained from the Bauxite mines of the Apennines, Istria and Abbruzzo (with the Bayer method using caustic soda) and from Leucite rocks (Blanc process), and-together with alloys and other products that exploited national resources-became an autarchic material par for excellence (Bernardini and Falco 1992, pp. 105-34).

The cold qualities of stainless steel and aluminum alloys well interpreted the desire for simplicity and "comfort" that distinguished modernity. The application field of light alloys extended to the 
furniture design in series characterized by the use of the metal tubular, which, starting in the second half of the twenties, developed according to the contemporary foreign examples.

The large-scale use of glass was made possible by the development of new transformation processes. With the Fourcault and Libbey Owens machine systems, the mass production of slabs and heat treatments developed and contributed to widening the field of possible applications (Figure 7). The qualities of safety crystals, translucent diffusers for glass-block structures, glass fibers, Termolux, and colored dye coatings were thus associated with the rational conception of space and a new general orientation of taste (Bernardini and Falco 1992, pp. 105-34). In the rationalism works, safety glass became real design materials. Testimonies are the solutions studied by Gio Ponti for the entrance shelter and the balcony doors of the central body in the Palazzo for Offices Montecatini (1936-1938) (Diotallevi and Marescotti 1939, pp. 21-133).

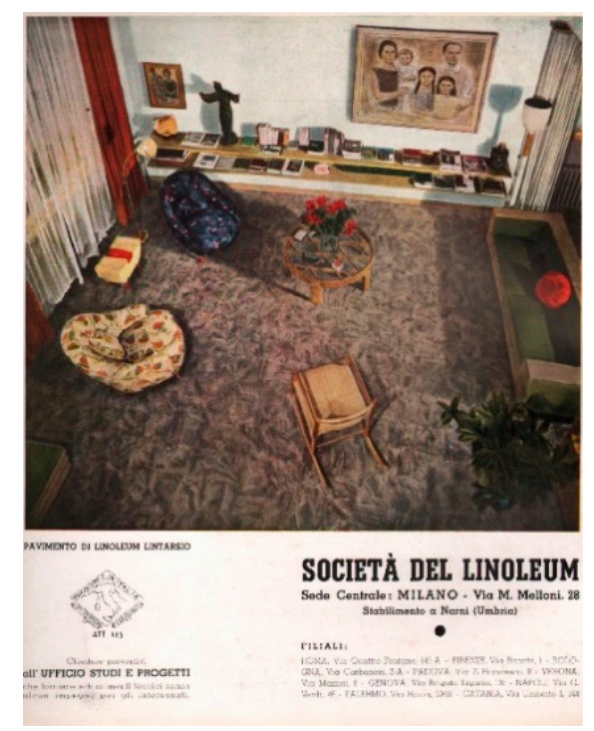

Figure 5. Advertising of Linoleum. Image from Casabella (1937).

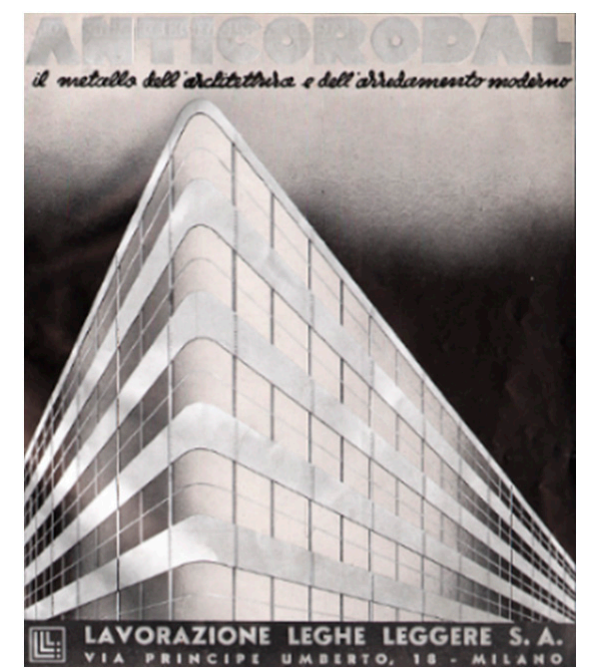

Figure 6. Advertising of L.L.L. (Lavorazione Leghe Leggere) company. Anticorodal. Image from Casabella (1936). 


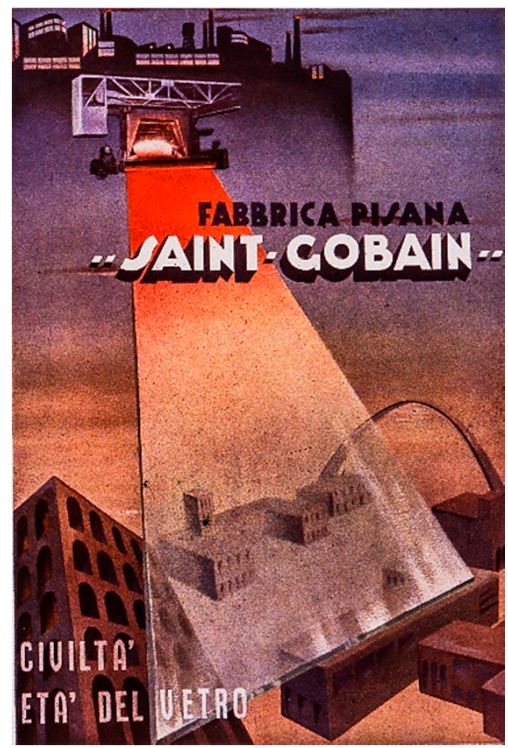

Figure 7. Advertising of Fabbrica Pisana St-Gobain. Image from Civiltà (1940).

In the middle of the 1930s, while the use of glass in architecture was well established, its multiple application possibilities in furniture and object design had not yet been fully tested. The creation of "unbreakable" objects developed over a few years with pieces that have since become design icons.

Some examples are the "Veliero" bookcase, a tensile structure in ash, tempered glass, brass, and steel, designed by Franco Albini in 1938 for his house in Via de Togni (Figure 8) and the radio cabinet where the mechanical parts are exposed between two slabs of Securit, that Albini always designed for the Wohnbedarf competition in Zurich (1940) (Figure 9).

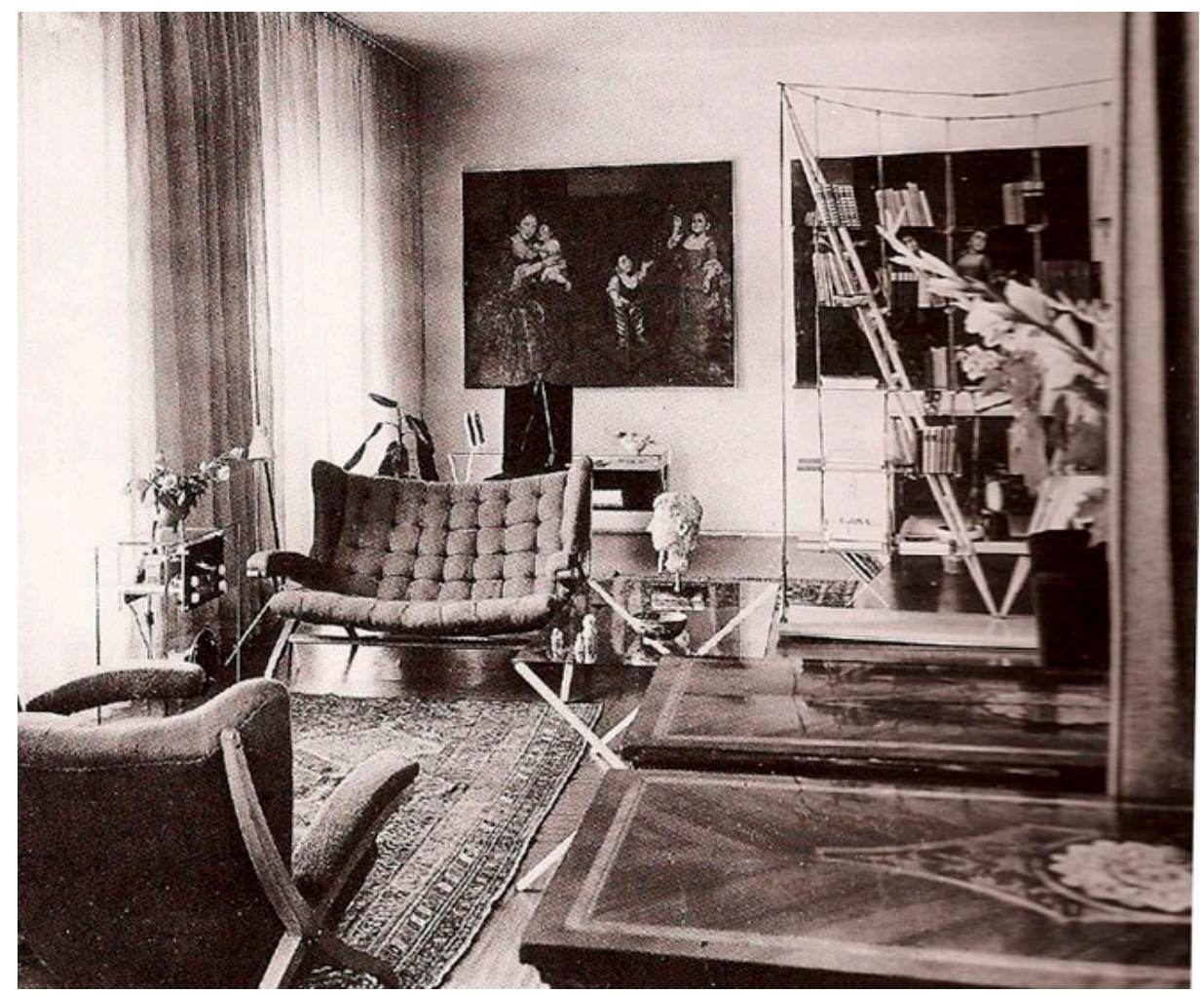

Figure 8. The bookcase "Veliero" in the living room of Albini's flat (1938). Photo from (Romano 1941). 


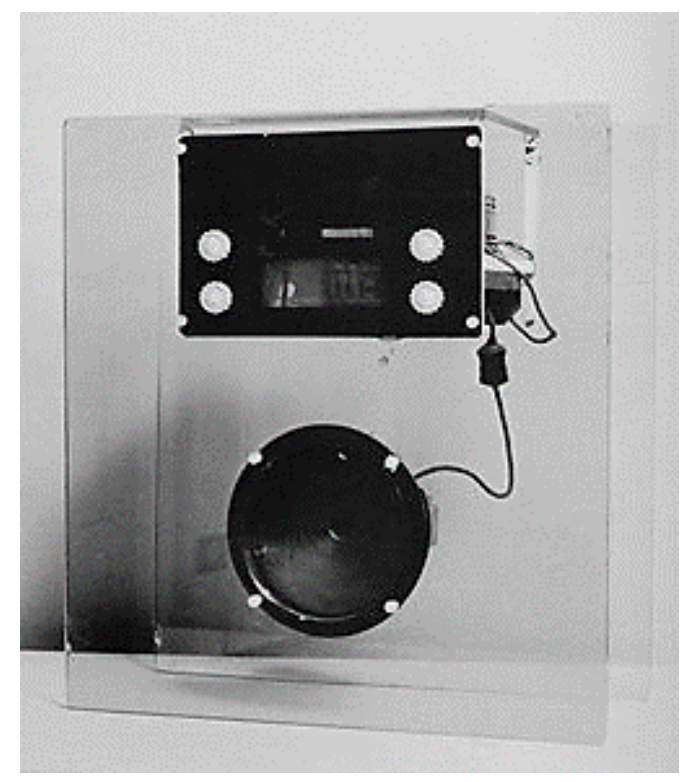

Figure 9. Franco Albini. The radio cabinet (1938-1940). The final project was presented for the Wohnbedarf competition in Zurich (1940). Image from Domus (1941).

Therefore, innovative technologies allowed the experimentation of new types. Employed individually or with other autarkic products, they participated in all fields of the project to define new forms. Autarky extended to every productive sector, triggering synergies between science and exploitation of national resources and important research on synthetic rubber that announced the excellent results achieved in the field of polymerization by Giulio Natta in the post-war period.

However, the scientific and technical efforts did not correspond to the ambition of the fascist autarchic plan, and the shortage of raw materials and production technologies brought Italy to face the Second World War with a notable lack of means and resources, a reality that was stubbornly denied by the regime (Maiocchi 2013).

Obviously, almost all countries involved in the Second World War had to face the problems arising from the scarcity of raw materials with the consequent production of surrogates and the necessity of recycling products and materials. It was a total mobilization that steamrolled any productive sector. In this theme, the historian of architecture Jean-Louis Cohen (2011) curated the important exhibition, "Architecture en uniforme. Projeter et construire dans la seconde guerre mondiale", which took place at the Centre Canadien d'Architecture of Montreal in 2011, emphasizing the research aimed at developing innovative products and processes with relevant implications for everyday life.

\subsection{The Ideological Influence of the Regime on the Rationalism: The Design Research for Modernity of Young Italian Architects}

In the autarchic context, research on the greatest Italian rationalism architects was undertaken under the sign of a complex and contradictory relationship with the regime. This relationship was recently revised by the historian Emilio Gentile (Gentile 2002, 2007), who clearly outlines the prominent mark left by Mussolini on Italian soil.

Between the two world wars, in Italian cities, a political conception materialized; it proposed the model of a new and universal imperial civilization similar to the Roman model of the ancient world. The fundamental ideological elements were the concept of universality over time, considered by Mussolini to be the essence of Romanity and the core of Italianism, and the legacy of the past was manipulated according to the fascist political ideology to create the future.

Cities, architecture, and even objects of this period can be understood through the reinterpretation of Romanism according to fascism, whose primary objective was the regeneration of the myth of Rome 
and its Empire-a regeneration that, in 1938 and with racial laws, was extended to the grim project of the regeneration of the Italian "race" (Gentile 2007). On 9 May 1936, Mussolini announced from the balcony of Palazzo Venezia the reappearance of the empire on the fatal hills of Rome, an empire that, with three overseas colonies, lasted only five years (Rodogno 2006).

Rome had been profoundly transformed under the first fourteen years of dictatorship through a sort of ideological petrification that developed from the Foro Italico to Via della Conciliazione.

It expanded from Piazza Augusto Imperatore to Via dei Fori Imperiali (the archaeological area between Piazza Venezia and Colosseum), and it branched out into the new campus of Sapienza University and the Garbatella district. From there, it was extended to the metaphysic architecture of the E42 area, which began construction when the regime was about to collapse (Cederna 1979; Insolera 1962).

Between the two world wars, the urban, architectural, and even the Italian design played a decisive game. The way of conceiving urban space changed, and the architecture became established as a public language. This historical turning point that saw the passage of Rome to international capital found its own set of issues in the relationship between the design culture renewal and the fascist ideology (Muntoni 2010, p. IX).

The new urban planning of Rome was stratified between the Roman ruins and the baroque churches in the infrastructures, the buildings, the streets, and with the projects of the main young Italian architects and artists of the time-Enrico Del Debbio, Mario De Renzi, Adalberto Libera, Gaetano Minnucci, Luigi Moretti, Giuseppe Pagano, Mario Ridolfi, Mario Sironi, and Marcello Piacentini (Ciucci 2002). The young architects tried to move the previous generation approach, linked to a rhetorical and monumental style, towards the European modernity. In a context in which fascism gave ample job opportunities to all professionals, the new architects' education played a central role (Muntoni 2010, p. XII).

In fact, the search for a modern Italian style was associated with the evolution of the architect's profile, a professional who had to exercise skills related to general culture, techniques, and arts. This profile was named "the integral architect" and was defined by the training programs of the "Regia Scuola di Architettura di Roma" in 1919 by Gustavo Giovannoni and Manfredo Manfredi, and later on by the Engineers and Architects Register in 1923 and 1925 (Ciucci 2002; Dal Falco 2017, pp. 28-35).

The specificity of the idea of integral architect is therefore linked to the foundation of the Schools of Architecture achieved by integrating the Schools of Engineering with the Academies of Fine Arts. Most of the credit for this initiative is due to Gustavo Giovannoni (1873-1947), historian, critic of architecture, engineer, architect, and urban planner who concluded a process that started at the end of the nineteenth century in Italy and in Europe. Giovannoni's training project was original and ambitious because it integrated the technical scientific culture with the humanities and the arts, the latter cultivated only in the Institutes of Fine Arts. The teaching of design was based on this synthesis, and an operative study of the history of architecture was considered the basis for the profession of architecture.

Giovannoni's project had a precise cultural identity, especially if we compare it with other European schools of the period, for example, with the Bauhaus born in the same year of the School of Rome (1919). One of the main differences lies in the fact that the Bauhaus theorized the exclusion of historical studies from its curriculum. On the contrary, for the School of Architecture of Rome, the knowledge of the past was the indispensable condition of architectural education.

According to the Giovannoni theory, all the disciplines had to converge to the "architectural project", which corresponded to the organic profile of the integral architect, the synthesis of technical, artistic, and classical culture skills. The new didactic program-and consequently the integral architect-led to the rebirth of an authentic style of modern Italian architecture.

The new figurative and technical constructive language, although it considered the international scenarios, had to be cohesive with the climate and customs of national life and had to reinterpret the forms of the past in a modern way. Therefore, the renewal of Italian architecture could not ignore tradition, and the integral architect had to know the millennial stratifications that characterize the Italian cities and Rome in particular. 
Giovannoni left the direction of the School of Architecture in Rome to Marcello Piacentini (1881-1960), academic of Italy as well as an architect and urbanist. Piacentini's interest (Piacentini 1930) in international experiences did not influence his cultural project; a return to the principles of classicism that should have substantiated the spirit of modern Italian architecture in a national and autarchic sense manifested. His proposal for an updated and polished monumentality devoid of decorative excesses without abolishing arches and columns was repeatedly disputed by Giuseppe Pagano Pogatschnig (Pagano Pogatschnig 1938) and Edoardo Persico (Persico 1933, 1934). This passage is fundamental for understanding the characteristics of Italian modernity, which was conditioned by the policies of the regime and autarky but also by the peculiar training guidelines established for architects (D'Amato 2017, pp. 33-46).

The integral approach of Italian architecture and design emphasized-on the one hand-the ability to design at all scales "from the spoon to the town" according to the principles of the modern movement, and —on the other hand — the knowledge and reinterpretation of historical heritage.

This approach was used from urban planning to the design of interiors and furniture so as to create houses, schools, and hospitals with morphological and constructive features that balanced modernity and traditions in old cities, newly founded cities, and colonized territories. The integral architect had to be able to design the planning scales and be informed about historical, technical, and artistic issues.

University educated young people who joined the regime asked for new criteria in the design of public works. At the beginning, the most retrospective academics prevailed, proposing a monumental style close to the "cult of the lictorian". Later, thanks to competitions (1925-1940) for public works (public housing, student houses, postal buildings, auditoriums, ministerial offices, stations, bridges), the best and youngest architects-among which were Libera, Mazzoni, Michelucci, Moretti, Pagano, Ponti, Ridolfi, Terragni, Banfi, Belgiojoso, Peressutti, and Rogers-completed important works linked to everyday life needs. Some of them changed their political opinions, moving from adherence to fascism, to the frond, and finally to the opposition (Melograni 2008).

The architect's talent responded to the "Zeitgeist" according to experimental figurative languages consistent with international modernity despite the insistent calls for a monumental conception. The Northern Italy architecture, particularly the Lombard one, has always been considered lighter and closer to the modern movement compared to what prevailed in Rome (Melograni 2008). Franco Purini pointed out that in Rome's architecture of the thirties, there were strong three-dimensional and volumetric values with a widespread use of the rounded corner that was different from the sharp corners of the Milanese buildings.

In public and private residential buildings, the inspiration from Mendelsohn's architecture is constant. Naturally, the realization is carried out through typological, structural, and formal criteria based on a classic taste more or less accentuated at the discretion of each architect (Spesso 2017). Other elements that allow us to understand the importance of the relationship between architects of this period and ancient Rome are the vaulted structure, the curved space, and the sinuosity that can be seen in certain projects (Muntoni 2010, p. XV).

In Italian modernity, these complex and sometimes contradictory elements coexist with references to both classicism and the modern movement. The relationships developed by the Italian architects with international modernist currents constitute a historical-critical crux.

Going deeper into this issue would require reference to a vast body of literature, and its complexity makes it impossible to treat herein as exhaustive as it goes far beyond the scope of this article.

What should be clear, however, is that Italy was not isolated, and European and North American architectural experiences were known through magazines such as Casabella, Architettura, and Domus and through important books such as Architettura d'oggi by Marcello Piacentini (1930) and Gli Elementi dell'architettura funzionale by Alberto Sartoris (1932, 1941), in which the most important modern architectural accomplishments of other countries were illustrated and discussed.

The complexity mentioned above is reflected in the constructive characteristics of the buildings. In fact, in Italian modern architecture and design, autarkic materials were used according to a conception 
of modernity in balance with tradition. The rational forms were made with new industrial types combined with the traditional vertical and horizontal coatings, such as marble and stone slabs (Poretti 1992). With a technological mix of traditional and innovative materials, the architecture and furnishings were influenced by the autarky that ranged from the early twenties to the early forties of the twentieth century, when it turned into a war economy. The search for a balance between tradition and innovation is evident both in compositional and constructive aspects. In Section 2.3, we see how the different architectures are linked by common themes.

Among the first buildings built in Rome that can be considered modern are the Post Office buildings (1933-1935). These are four very different representative buildings of the new metropolis (Muntoni 2010, p. 270). The buildings by Adalberto Libera and Mario De Renzi and by Mario Ridolfi and Giuseppe Samonà have a non-rhetorical and unconventional character. The relationship with the historical pre-existences and the compositional inspiration of Roman and Baroque architecture (stairways, drums, concave-convex rhythmic alternation) is subtended by a skillful technological mix made of reinforced concrete structures and stone cladding. The Viale Mazzini building designed by Armando Titta, a Turin architect, retains the stereotypical trait of the regime's public building (Poretti 1990, pp. 5-9).

The Post Office building by Libera and De Renzi is a symmetrical and massive C-shaped volume in which an elliptical skylight is fitted with opaline glass and metal profiles. A portico clad in dark porphyry flanks the building, connecting it to the street by a stairway. On the short fronts, two large openings illuminate the back stairs with a unique game of diagonally woven grids. The back is a plate of "stone-concrete" pierced by small square openings (Dal Falco 2002, pp. 129-48, Poretti 1990, pp. 39-84) (Figures 10 and 11).

Also, the Post Office building by Mario Ridolfi presents a symmetrical but curvilinear and continuous structure with a concavity in the central part, and the ends are resolved with two rounded corners. A shelter is detached from the roof, which underlines the sinuous structure of the building. The building plastic qualities are enhanced by a continuous travertine cladding on which there are rectangular windows at regular intervals (Dal Falco 2002, pp. 149-81; Poretti 1990, pp. 85-123) (Figure 12).

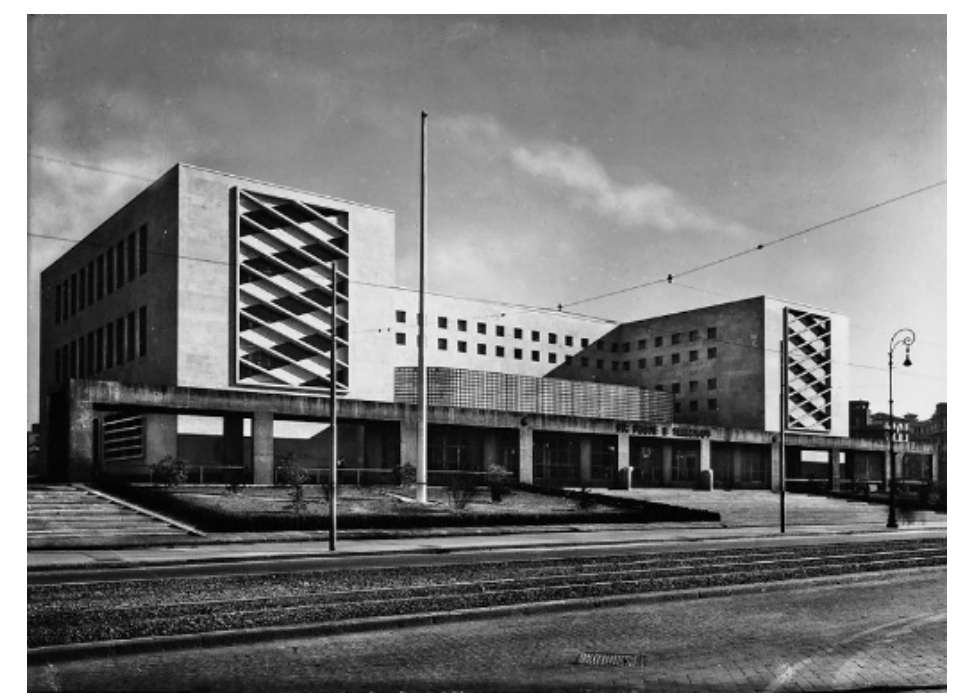

Figure 10. Post Office building by Adalberto Libera and Mario De Renzi. Rome (1933-1935). Photo from (Pica 1936, p. 301). 


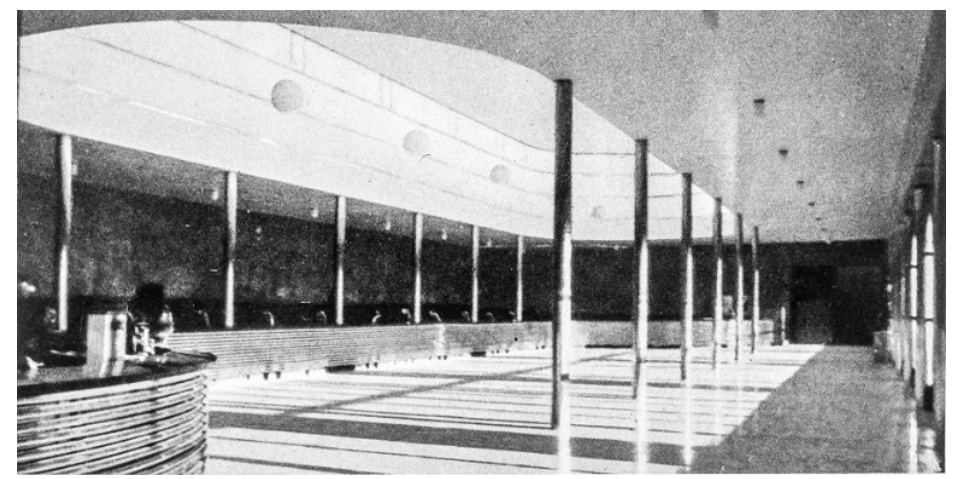

Figure 11. Post Office building by Adalberto Libera and Mario De Renzi. Rome (1933-1935). The hall. Photo from (Pica 1936, p. 301).

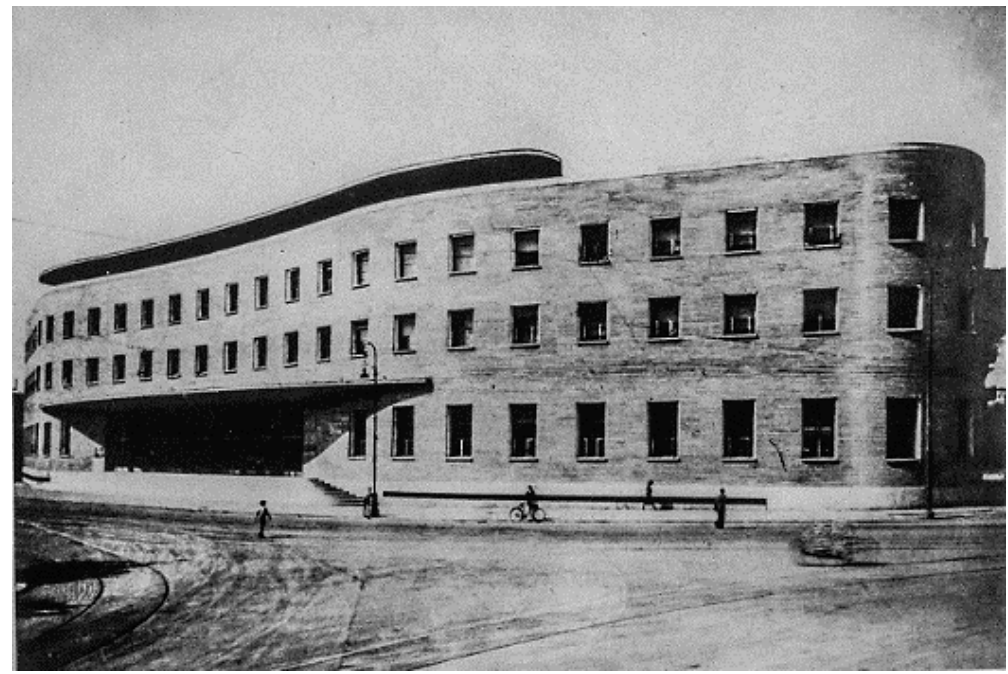

Figure 12. Post Office building by Mario Ridolfi. Rome (1933-1935). Photo from (Poretti 1990, p. 88. Source: Museo storico delle poste e telecomunicazioni).

The Post Office building by Giuseppe Samonà is composed of two V-wings that close in a convex corner and a parallelepiped placed on the secondary front. The base is characterized by large windows placed between the reinforced concrete pillars covered with Samolaco gneiss slabs while the upper facades are covered with travertino (Dal Falco 2002, pp. 185-201; Poretti 1990, pp. 125-62) (Figure 13).

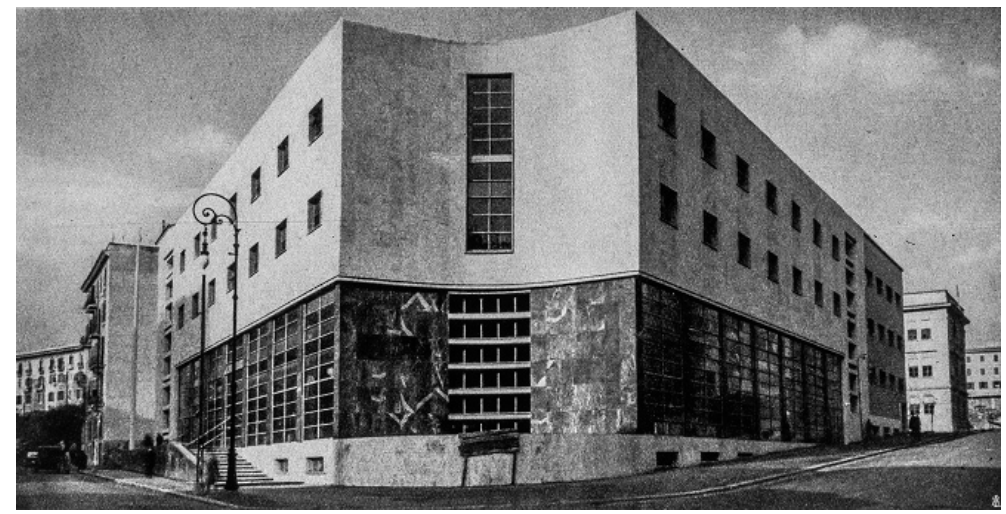

Figure 13. Post Office building by Giuseppe Samonà. Rome (1933-1935). Photo from (Minnucci 1933, p. 607). 
These three architectures, which have been the subject of important studies, are examples of the particular tradition and innovation mix that characterized the Italian production between the two world wars. Moreover, they are significant to understanding how, despite the conditionings of the regime and autarky, the young Italian architects succeeded in pursuing the Italian modernity way with the aim of changing lifestyles in the habitat, both private and public.

\subsection{Architectural Themes: A Unique Technological Mix}

The Italian architecture of the period is therefore unique compared to modern architecture. Even if there are analogies between the Italian and the European experience, the Italian rationalist architectures are characterized by a strong innovation without precluding ties with history or references to Romanity and the typical figures of Italian architecture, such as the Renaissance loggia, the bell tower, and the internal court. Even the constructive elements were characterized by a particular material and technological mix consisting of traditional materials, innovative products, and technologies. Starting from this assumption, it is possible to define architectural themes that unite important buildings of the period: structure and closing diaphragms, coverings in stone materials and Klinker, flat roofs, and iron frames.

The structural theme was exemplified in the facades that, with their order and their materiality, represented meanings and communicated messages related to the historical context.

This theme is linked to the use of isolating materials, which, as mentioned in Section 2.1, constituted an important productive sector responding to the autarchic principles. The reinforced concrete allowed the rationalization and reorganization of the interior spaces and the design of facades free from the structure. In some exemplary cases, as in the Loggia del Casa del Fascio (Como, 1933-1935) by Giuseppe Terragni (Marcianò 1987; Saggio 1995) and in the elevations of the Palazzo delle Poste (E42, 1939-1941) by Banfi, Belgiojoso, Peressutti, and Rogers (Danesi and Patetta 1976), the reinforced concrete skeletons covered in marble slabs are on an advanced plane in respect to the perimeter walls (4).

This motif was used to build porticoes and bases whose large windows were divided horizontally by black-painted iron frames.

In the Casa del Fascio, the search for a new spatiality correlates to a poetic interpretation of the light. The Terragni building is a pure prism made of four different fronts, alternating smooth walls and pillar and beams grids that create light and dark effects (Arrigotti et al. 1936) (Figure 14).

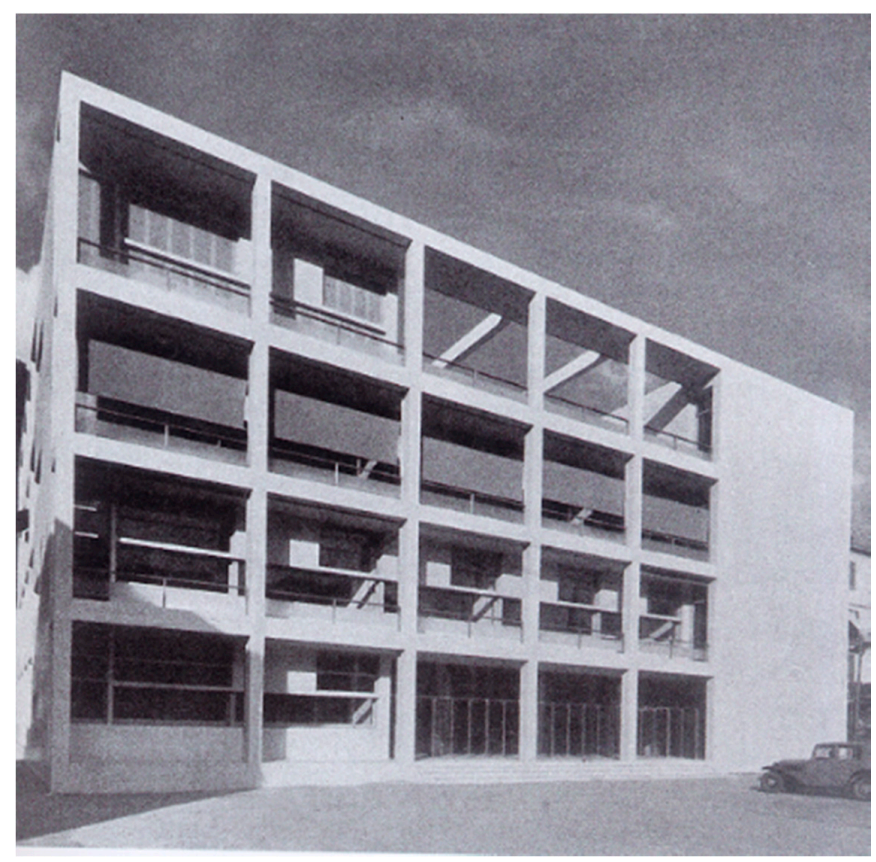

Figure 14. Casa del fascio by Giuseppe Terragni. Como (1932-1936). Photo from (Sartoris 1941, p. 387). 
The practicable flat roof is partly covered by a glass-block skylight that illuminates the double height of the internal courtyard. The opalescent light matches the Botticino light stone cladding.

In the Casa del Fascio, the search for a new spatiality correlates to a poetic interpretation of the light. As in French and German architectures (5), Terragni experimented with new glass curtain walls and glass blocks. For this reason, the Casa del Fascio is considered the manifesto of the use of glass products (Artioli 1989), an emblem of modernity that simultaneously illustrates transparency and fascist ideas - the control from the outside to the inside and vice versa (Ciucci 2002) (Figure 15).

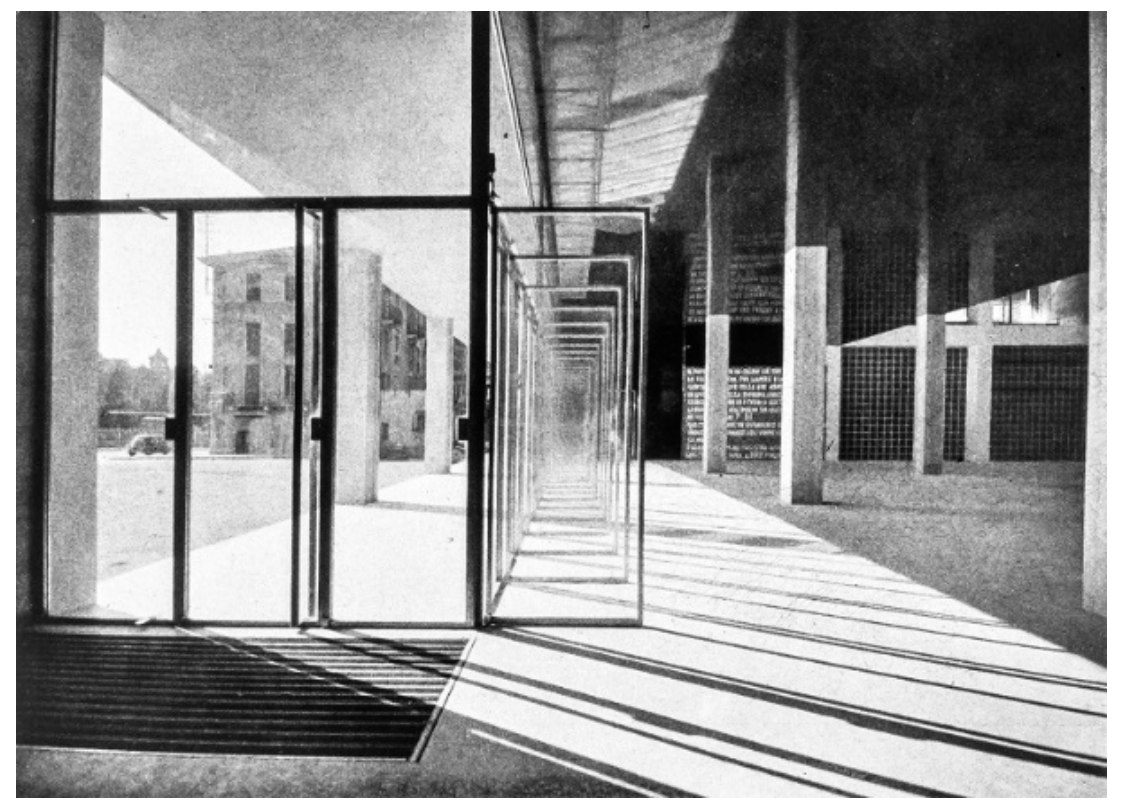

Figure 15. Casa del fascio by Giuseppe Terragni. Como (1932-1936). The entrance with the Securit glass doors. Photo from (Sartoris 1941, p. 395).

The structure coincided with the facade plan. In the Montecatini office building (Milan, 1936-1938) by Gio Ponti, the skeleton is a perforated box of reinforced concrete on which the Cipollino Apuano marble cladding was applied (Diotallevi and Marescotti 1939, pp. 21-133). The frames in light aluminum alloy (Anticorodal) were placed on the edge of the cladding, generating a great structural image (Irace 1977).

The stone cladding is a central theme in the architecture of Italian rationalism and strongly identifies its style. The pure volumes of the new modern aesthetic necessitated clear surfaces and symbolic materials consistent with autarkic needs. Marbles, stones and granites were extracted from ancient quarries like those of the Apuan Alps in Tuscany and were used in thin slabs.

The construction procedures were experimental and worked with innovative techniques. Marbles and granites were used to cover the exteriors, usually white, while for the interiors, colored stones were preferred (Poretti 1992, 2013). Stone materials were coupled with petrifying plasters and ceramic and glass mosaics whose industrialized production allowed the creation of durable and economic decorative surfaces that recalled ancient Byzantine mosaic arts (Bernardini 2017, pp. 159-72).

Moreover, the Carrara or Travertino marble blocks were used for paving or for architectural details-frames, jambs, thresholds, and sleeves thick up to $8 \mathrm{~cm}$ with rounded edges, assembled protruding from the edge of the facade and worked with slight slopes to dispose of rainwater.

It is to be noticed that the use of stones in the foreground entailed the careful study of textures and details_colors, dimensions, arrangement of elements, joints, surface treatments, and installation systems adopted are all elements that generate perceptual values.

Beside the coverings of the mentioned buildings, the coverings of two architectures that are beacons of the Italian rationalism are emblematic, namely the coverings of the House of the G.I.L. (Gioventù Italiana Littoria) (1932-1937) and the House of Arms (1933-1936) by Luigi Moretti. 
The House of the G.I.L. is articulated into distinct volumes characterized by a complex of linguistic elements that are wisely intertwined.

The tower, an emblematic reference to a bell tower, has a tapered front coated with travertine slabs on the square. A fixed and continuous glazed surface wraps the corner between Via Induno and Largo Ascianghi from the base up to the top. The motif of horizontal partitions created by the iron frames is typical of the architecture of this period and of Moretti in particular.

The reinforced concrete structure is visible on the glazed side facades and on the block of gyms devoid of any cladding.

From the construction drawings, one can grasp the care devoted by Moretti to the design of the tower's covering. The 370 rectangular slabs of variable size were divided into 19 types. Moretti drew a filing cabinet consisting of 171 pieces numbered in alphabetical order specifying size and thickness (Figure 16). This attention to the construction detail and the technical drawing is typical of Rome's School of Rationalism, and it is particularly present in Moretti's projectual research (Architettura 1941, Marconi 1941, pp. 361-73).

In the Foro Italico's House of Arms, the theme of cladding-made of Carrara's statuary veined marble-is developed in an exemplary way. The rationalist box is interpreted as a marble, modern, and monumental organism. All facades are designed in detail, and any shaped block is numbered.

Special pieces are designed to obtain rounded corners. The marble plasticity of the building is accentuated by the continuity among the base, the access flight steps, and the external flooring (Marconi 1937, pp. 437-54.) (Figure 17).

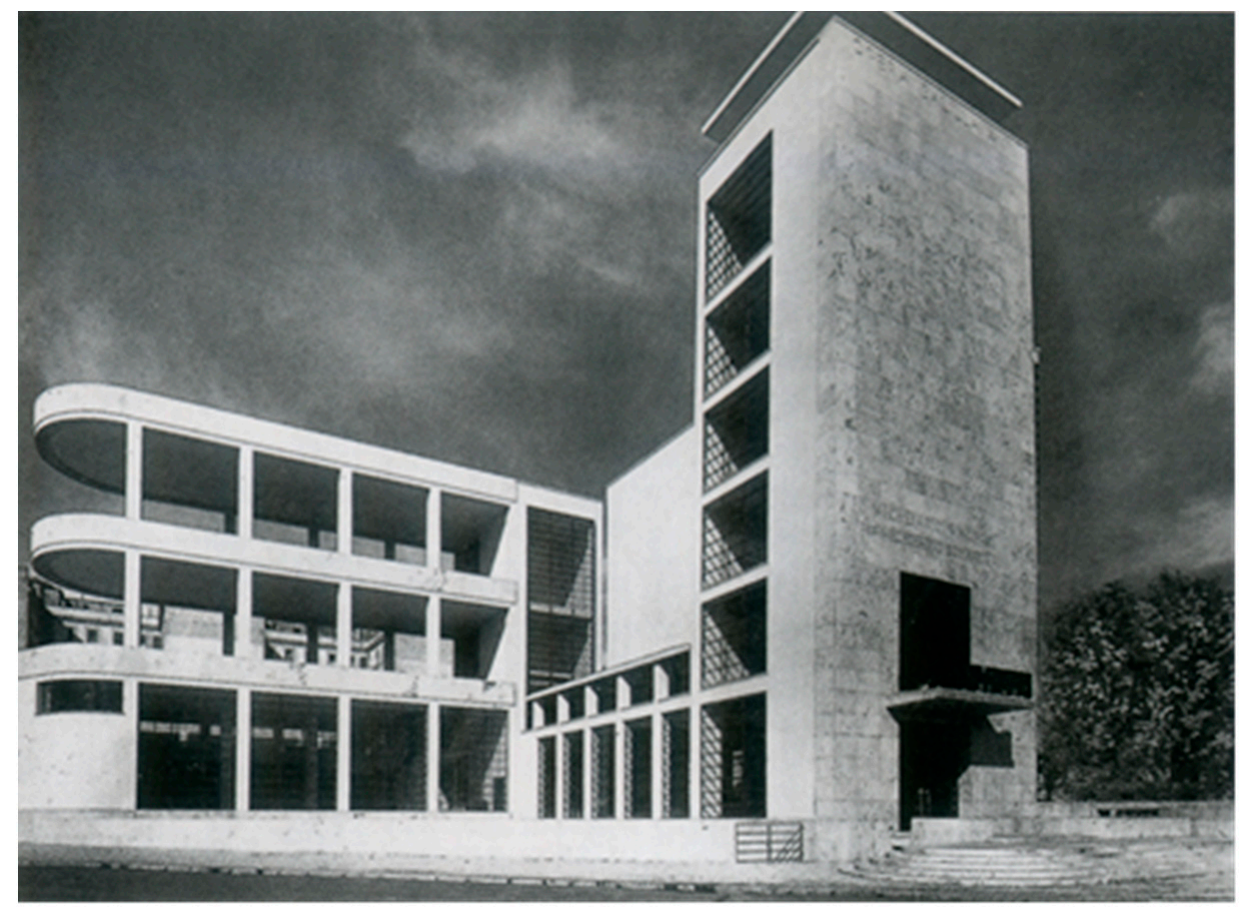

Figure 16. Luigi Moretti. House of G.I.L. Rome (1932-1937). The tower and outdoor gyms. Photo from (Marconi 1941, p. 361). 

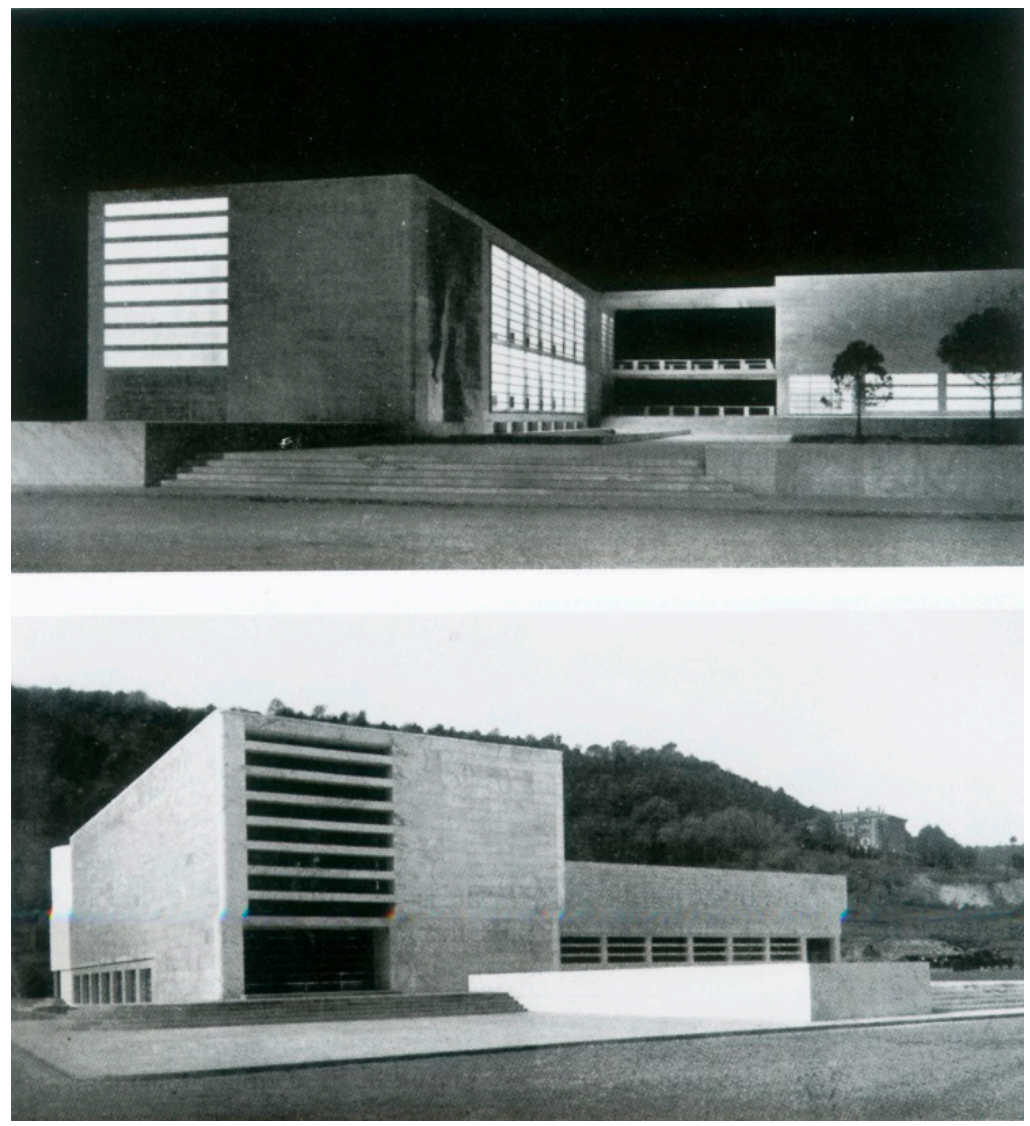

Figure 17. House of Arms of Luigi Moretti. Rome (1933-1936). The block of the fencing room. Vertical covering in statuary veined Carrara marble. Photo from (Marconi 1937, pp. 440, 443).

The third theme is the flat roof. Flats roofs were associated with the concept of squared and clear facades-practicable terraces, sometimes used as a solarium, or glass-block skylights (Figure 18).

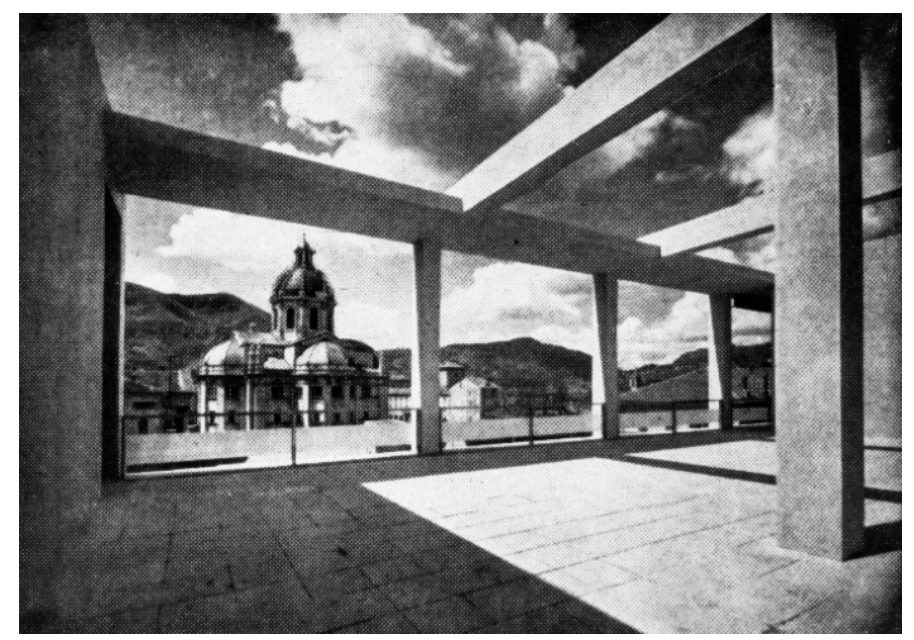

Figure 18. Casa del fascio by Giuseppe Terragni. Como (1932-1936). The terrace. Photo from (Sartoris 1941, p. 399).

In the Congress Palace $(1937-1942,1953)$ by Adalberto Libera built for the E42, the roof of the congress hall is flat and practicable. The terrace is designed as an open-air theater and furnished with 210 fixed benches, covered with marble and carefully placed in relation to the flooring texture (Palazzo delle Feste 1938) (Figure 19). 


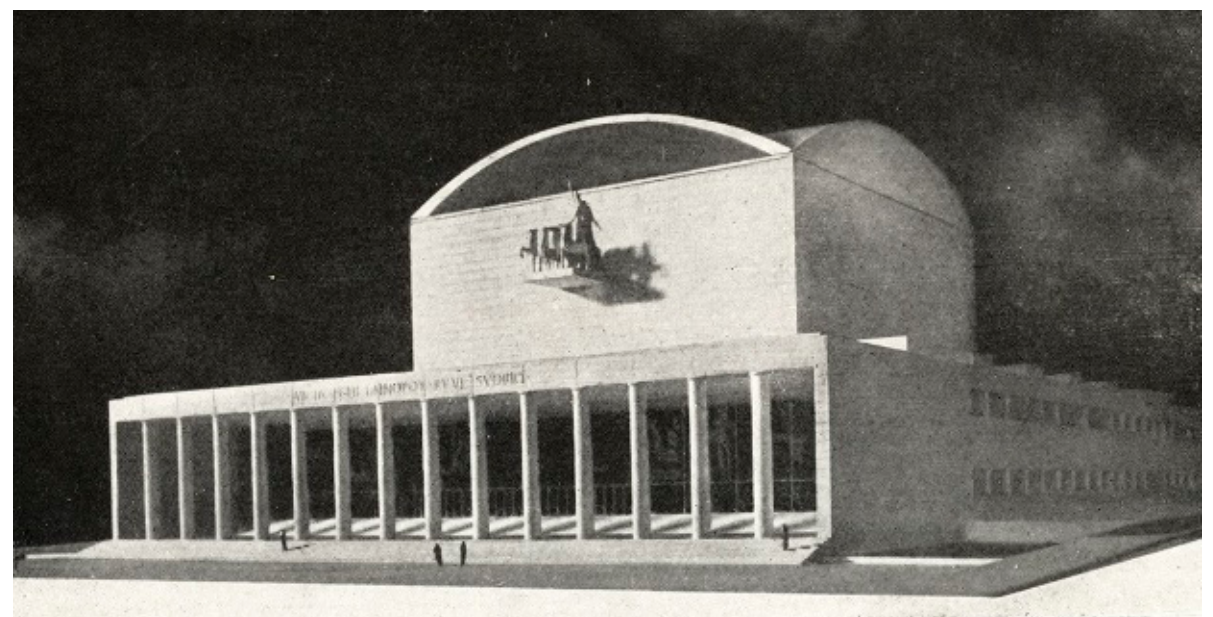

Figure 19. Congress Palace by Adalberto Libera. E42 (1937-1942, 1953). Wiew of model. Photo from (Palazzo delle Feste 1938, p. 785).

A fourth theme concerns the design of window frames in iron or aluminum alloys, such as Anticorodal, based on the component standardization and experimentation with innovative assembly methods for profiles (Figure 20). As mentioned, since the end of the 1920s, the production of white metals was strongly boosted. Their use on a large scale responded to the combination of economic factors and new technological design requirements-window frames, balustrades, handles, and furniture in curved steel or aluminum tubing with plywood shelves, sometimes recovered in linoleum or Buxus (Dal Falco 2017, pp. 316-24). In the late 1930s works, there was a greater use of wooden frames than of metal profiles. On the other hand, the preparation for the war conflict limited the iron for military use. In a short time, the great season of design experiments that characterized rationalism in the mid-thirties ended.

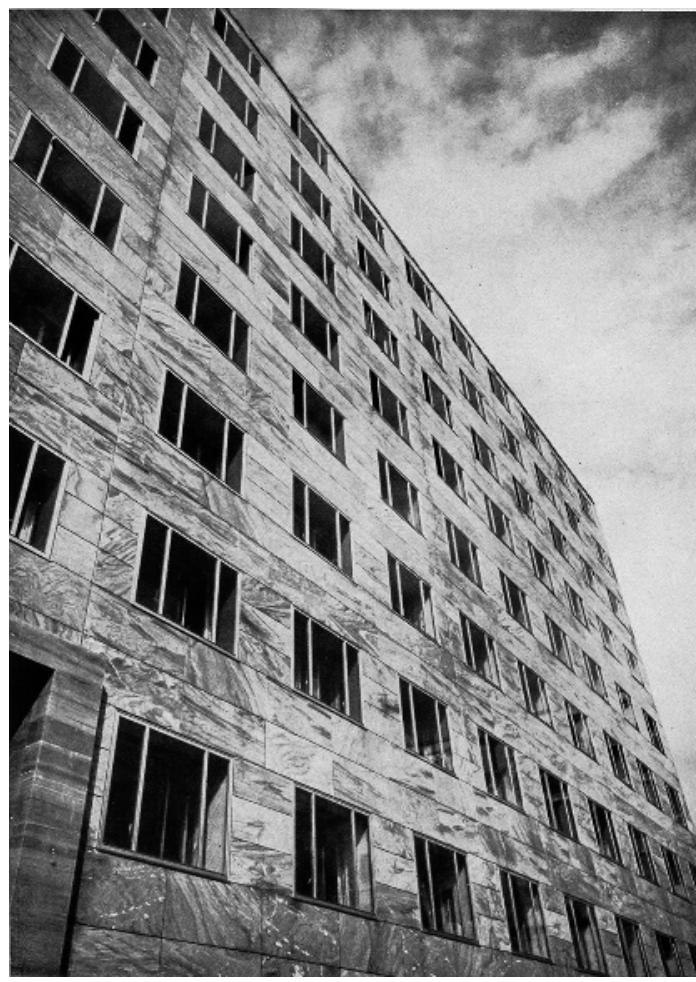

Figure 20. Montecatini office building by Gio Ponti. Milan (1936-1938). Side elevation. Cladding in cipollino apuano marble. Double Anticorodal frames. Photo form (Diotallevi and Marescotti 1939, p. 113). 


\subsection{Design Themes: Metal Furniture and Standard Production}

As mentioned above, the autarkic plan outlined by Mussolini on 23 March 1936 at the National Assembly of Corporations was mainly addressed to the restructuring of metallurgical, mechanical, and chemical industries, but it was implemented in all productive sectors, from construction to design and fashion. It was also supported by articles published in the main journals of the period (Architettura, Casabella, Domus, Rassegna di Architettura, Lo Stile nella casa e nell'arredamento).

In addition, new specialized magazines were born whose main scope was the dissemination of characteristics and applications of innovative materials (Alluminio, Il Vetro, Edilizia Moderna. La Rivista del Linoleum, L'Industria nazionale, Rivista mensile dell'autarchia).

Since the end of the twenties, in his magazine Domus, Gio Ponti published numerous appeals for the development of national production in the field of decorative and industrial arts (Ponti 1928, 1935, 1936) to which architects, engineers, technicians, and professionals responded (Ardissone 1936; Panseri 1936).

The debate on autarchy intensified in 1938 when experts from all productive sectors wrote articles (Pica 1937; Nunzi 1938), and there was a growing advertisement of national food, textiles, and pharmaceuticals with technical columns dedicated to autarchic building production.

The new integral architect should design—or at least find solutions-for the interior and the furnishings. Metal materials were the most innovative testing field with a strong interest in foreign productions both by architects and specialized firms.

The Italian furnishings followed the fashion of the time and were inspired by the Bauhaus models and in general by the German production that began in 1925 with the Wassily armchair by Marcel Breuer. This new way of design found its formal and structural reasons in the culture of the curved tubular profile (Marchis 1998).

As is known, the new European tendencies were shown in international exhibitions that some Italian architects had visited or known through some magazine. In the design of Italian furniture, one can find many compositional and constructive elements typical of the furnishings of 1927's "Ausstellung die Wohnung Stuttgart" coupled with the idea of human scale standards that was accomplished by Le Corbusier's "Pavillon de l'Esprit Nouveau" (1925).

The knowledge of foreign production in this field (in particular of furniture made in Switzerland and German) is proven by the relationships established between the company Colombo, created in Milan in 1919, and the Wohnbedarf of Zurich, founded by Sigfried Giedon, Werner M. Moser, and Rodolf Graber in 1931. Wohnbedarf models were, among other authors coming from the Bauhaus, designed by Breuer.

The Hungarian architect also designed for the companies Thonet and Embru, which in turn were linked to Wohnbedarf by a contract between the parties (Tropeano 1998; Crachi 1997). In this context, Colombus was one of the leading companies in the production of Präzisionsrohr and sold the Wohnbedarf furniture in Italy (Figure 21).

This system of functional and linear objects initially corresponded more to the taste of elites than to a demand for cheap furniture. It is only since the mid-thirties that metal furniture has been proposed in the catalogue by Italian companies (Columbus, Beltrami di Capriolo, Parma di Saronno, Pino di Parabiago) (Figure 22) and adopted in buildings and public spaces such as offices, schools, universities, hospitals, shops, and restaurants (Bassi 1988). A significant collaboration relationship was established between Giuseppe Pagano and the Columbus company, with whom the architect worked in 1934 for the furnishings of the offices of the newspaper "Il Popolo d'Italia" in Milan. Pagano designed, for the Columbus catalog, the hanger, the waste basket, and the umbrella stand (Bassi 1988). 


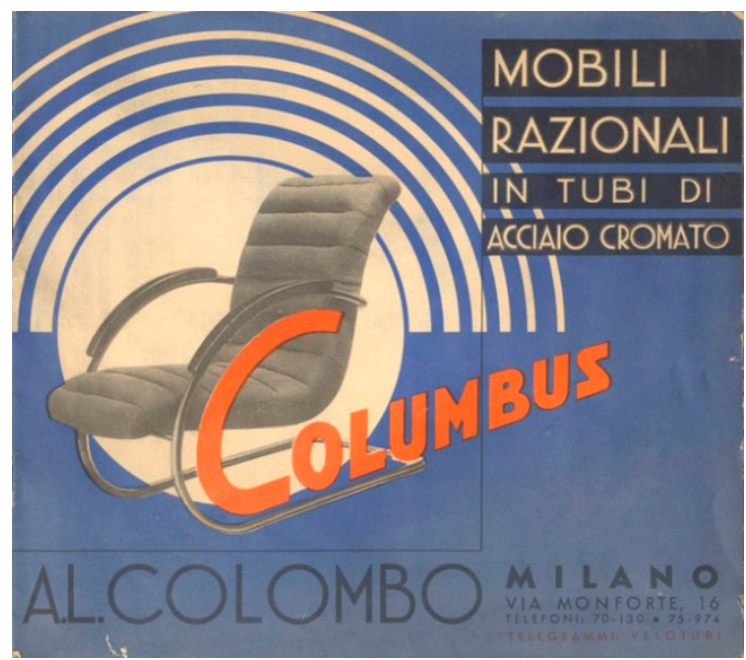

Figure 21. Advertising Columbus company.

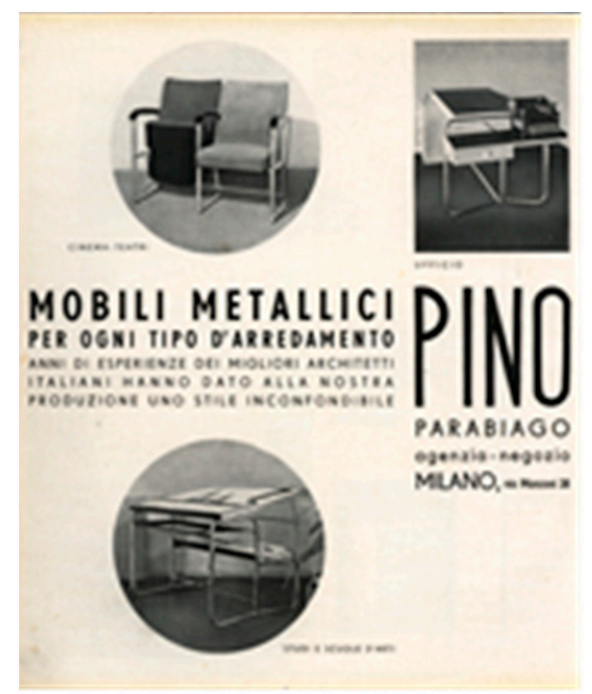

Figure 22. Advertising Pino Parabiago company.

In 1934, the Gommapiuma patent deposited by the Pirelli company developed a greater simplification of the structural part combined with the padding comfort (Pansera 1998).

The first Italian experimentations of steel, iron, and aluminum furniture began in 1930. The protagonists of this pioneering phase were Luigi Chessa and Umberto Cuzzi with the Bar Fiorina of Turin (1931-1932). Bar Fiorina's furnishings were considered in the pages of La Casa Bella (1932) as fully participating in the new European tendencies. Materials such as chromaluminum, bakelite, and crystal were utilized with an experimental approach so as to explore the potentialities of innovative technologies and promote the renewal of the city, even if at a small scale (Selvafolta 1980, p. 34) (Figure 23).

The research conducted by Gabriele Mucchi, maker of a radical renewal in this field, was very original. Between 1934 and 1935, Mucchi collaborated with the Pino company on a series of models. He designed them in a factory in direct contact with productive and economic issues following the prototyping phase (Figure 24). 


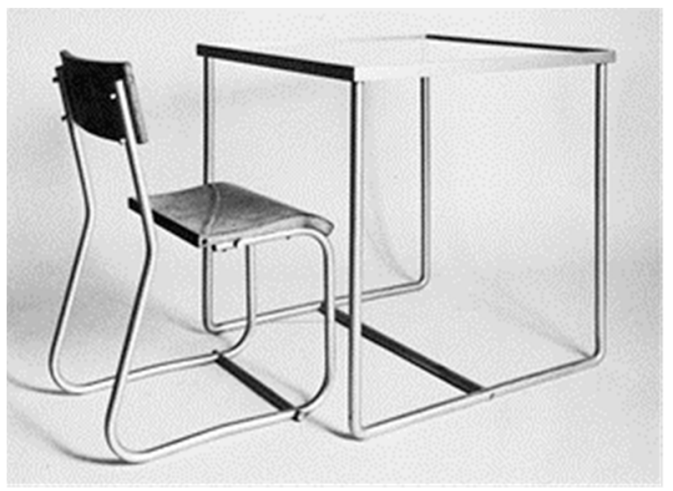

Figure 23. Chromium aluminum, crystal, and wood table and chairs by Gigi Chessa and Umberto Cuzzi (1931-1932). Photo from (Selvafolta 1980, p. 33).

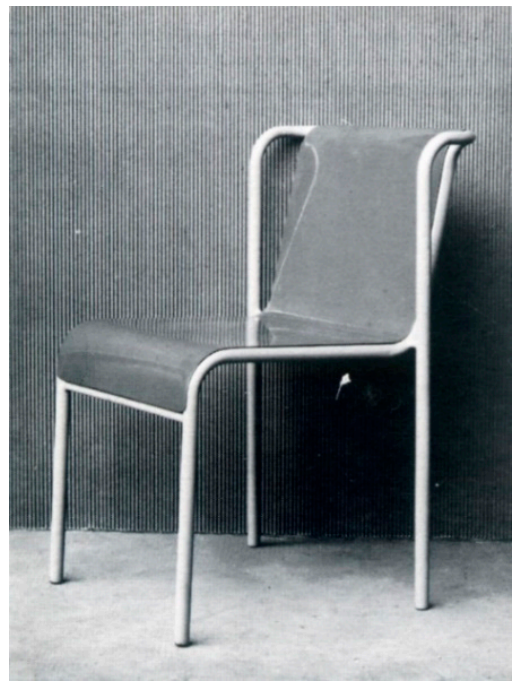

Figure 24. A stack chair, Model S5 by Gabriele Mucchi (1934-1935). Chromium plated steel structure and sheet steel seat. Photo from (Selvafolta 1980, p. 46).

Even if inspired by models coming from the north of the Alps, Mucchi's furniture was original in the rigorous use of the metallic tubular and in the sharp separation between load-bearing elements and parts that are borne. Among the types of stackable chairs, S5 (1936) stands out.

It is composed of two frames of chromed steel and a seat made out of sheet metal, raffia, cord, wood (Selvafolta 1980, p. 50). Milan's Triennials $(1933,1936)$ were the most important showcase for the design of metal furniture. At the 5th Triennial (1933), "Villa-Studio per un artista" by Luigi Figini and Gino Pollini was the manifesto of a vision of modern architecture founded on the Mediterranean tradition, a vision that wanted to distinguish itself from the standpoints of Mies van der Rohe and Le Corbusier in the name of rationalist solutions consistent with a different historical and natural background.

In "Villa-Studio", geometrical spaces are treated with delicate chromatic nuances, and the furniture consisted of few elements with steel frames and planes of colored glass paste for the tables. This synthetic overview cannot neglect Terragni as a designer.

The monographic issue of the journal Quadrante (1936) devoted to the "Casa del Fascio" praised Giuseppe Terragni for having taken integral care of the building, from its foundations to the making of its handles. The "Casa del Fascio" was defined-for the architecture and the interior-as the paradigm of a global approach aimed at achieving models of functionality and aesthetics and also of work methods and behavior (Selvafolta 1980, p. 52).

The furniture had to be consistent with the transparent-even ideological-image of the architecture containing them. Terragni designed light and non-bulky objects, entrusting their 
implementation to the firm Columbus; in this way, he created armchairs and elastic chairs that were very innovative relative to the guidelines of that time, which imposed rigidity and poise to the sitting posture.

The chair "Lariana" was composed of a seat with the back in bent plywood and a unique metallic frame, while the seat "Benita" was equipped with armrests and coated with a light padding. "Benita" was adopted for the Directory Room of "Casa del fascio" (1932-1936) (Figure 25) and for the offices of the day care "Sant'Elia" (1936-1937) (Figure 26), both in Como. For "Sant'Elia", Terragni engaged himself in the construction of furniture for children with a marked orientation towards a more classically familiar appearance.

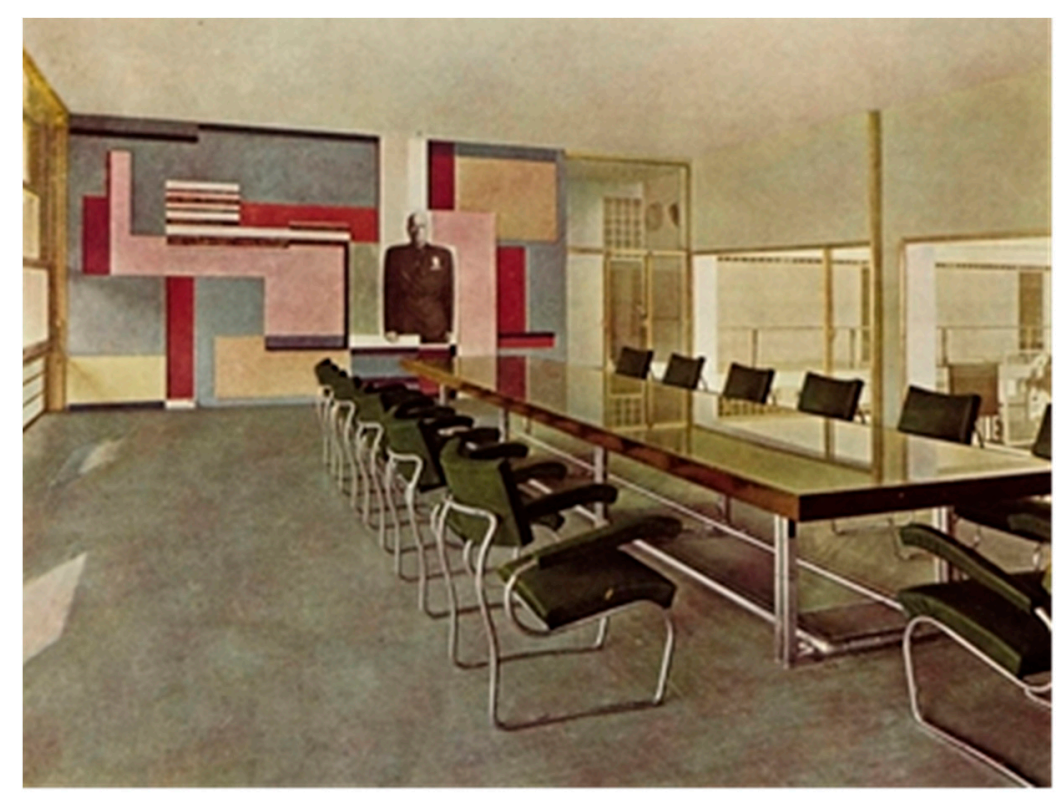

Figure 25. Casa del fascio by Giuseppe Terragni. Como (1932-1936). Directory room, table in chromed alpaca stiffened with anticorodal tubular. Top protected by glass sheet $140 \mathrm{~cm} \times 700 \mathrm{~cm}$, thickness $10 \mathrm{~mm}$. Fresco by Mario Radice. Armchairs model "Benita". Table and armchairs produced by the company Columbus. Photo from (Sartoris 1941, p. 398).

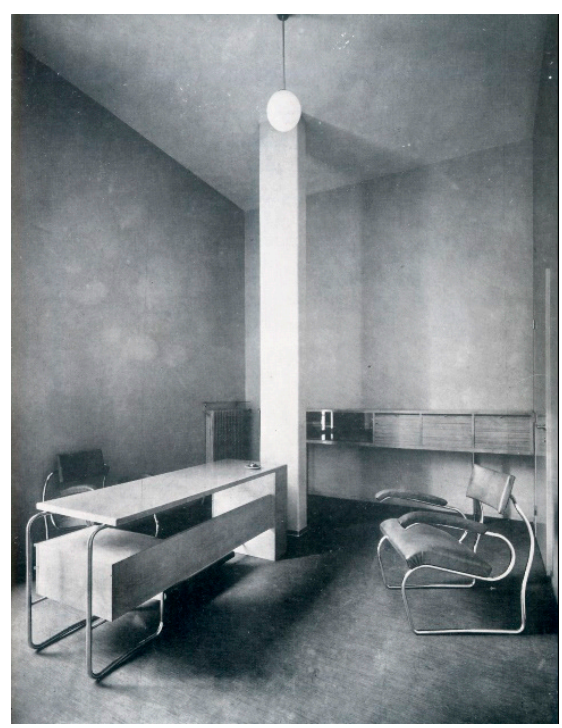

Figure 26. Day care "Sant'Elia" by Giuseppe Terragni. Como (1936-1937). Director's office with the "Benita" model armchair. Photo from (Crespi 1987). 
Even the new lighting equipment, mostly produced in series, were comparable with foreign production. The ceiling lamps, the table lamps, the appliqués, and the floor lamps were characterized by bases in aluminum or bronze alloys and by engraved or satinized opal glass diffusers, and they were widely used in factories and public and private buildings.

These innovative typologies introduced a different concept in interior lighting, contributing to the definition of the aesthetic of modernity, which, in design, finds a free space for experimentation (Padoan et al. 2018). Pietro Chiesa was among the most important designers of modern lamps. His activity dates back to 1921, when in Milan, he opened a workshop specialized in processing crystals and glasses with a production of very high quality objects.

In 1933, Chiesa joined the firm Fontana Arte as art director. The results of this fruitful collaboration were simple and elegant lamps but also more complex objects connected to his relationship with the decorative and applied arts (Selvafolta 1980, pp. 57-58; Ponti 1949).

This relationship between craftsmanship and industry is a peculiar trait of Italian design. It is worth noticing that, in parallel with the metal furniture and especially in Lombardy, artisans and small firms were continuing their production of furnishings and wooden objects.

From the beginning of the 1930s, a close collaboration between designers and manufacturers began when substitutes for wood were launched into the market.

The research aimed at functionality and the recovery of anonymous design of foldable tables made of strips and straw-bottomed chairs so as to modernize traditional objects by redesigning their shapes (Tonelli-Michail 1987, p. 89). Although it amounted to a minor production, it is not less interesting because it concerns the complex issue of the relationship between craftsmanship and industry typical of the Italian design culture.

\section{Architecture and Design in the Campus of the Sapienza University of Rome: The Institute of Physics by Giuseppe Pagano Pogatschnig, A Case Study}

\subsection{The Campus of Sapienza University of Rome}

An emblematic case of integral planning is the Campus of the Sapienza University of Rome built between 1933 and 1936 in record time (Figure 27).

The Campus, despite the interventions it has undergone in eighty years, still retains a clear architectural historicity and now is considered a heritage of architecture, arts, and design.

The urban plan of the campus, which in the intentions of the fascist regime was to become the main center of studies in the Mediterranean, was dated 1930 when the state assigned the University the building plot located in the east of Rome in one of the city expansion areas. Mussolini himself indicated the characteristics of the urban complex, specifying that the construction techniques must be Italian and innovative (Piacentini 1935; Guidi 1935).

The assignment was dated 1932, the project was defined in 1933, and the inauguration took place on 31 October 1935 in the presence of King Vittorio Emanuele III and Mussolini.

In 1932, Mussolini appointed Marcello Piacentini Chief Executive Officer and Chief Architect, who formed the team of young architects and organized a technical office dedicated to studies on university campuses and innovative technologies used abroad.

The role of Piacentini was fundamental in the Italian architecture of the 1930s.

He was recognized by Mussolini as an organized and cultural leader of the renewal of the architect profession. The choice of young architects who had to design the various university buildings did not include some of the best talents of rationalist architecture, such as Terragni and the Group BBPR.

Piacentini engaged only two protagonists of Milan's architectural culture, Giuseppe Pagano-the undisputed leader of the magazine Casabella—and the older Gio Ponti, coming from a modernist background.

Piacentini had to decide fast, and he selected architects that he had encountered in his decennial experience-Rome's professionals Pietro Aschieri and Giuseppe Capponi, together with Gaetano Minnucci and Eugenio Montuori, recently graduated from the Royal Architectural School of Rome, the students of Rome's School Francesco Fariello, Saverio Muratori, and Giorgio Calza Bini, the 
trusted Gaetano Rapisardi, a colleague in his professional firm, and Arnaldo Foschini, the closest to the monumental style sponsored by the regime. The Tuscan Giovanni Michelucci was also invited. Michelucci, together with the Toscano Group (Pier Niccolò Berardi, Nello Baroni, Italo Gamberini, Sarre Guarnieri, Leonardo Lusanna) had just won the competition for the new station of Florence Santa Maria Novella (1933-1935).

The project, which was built in parallel with Sapienza Campus, was the first example in Italy of a station conceived according to logic of modern functionality.

Sapienza Campus is the representation of a particular architectural climate in which this team of architects of different cultures and generations worked together. An urban complex linked to the Roman architectural tradition emerged from the collaboration of the architects' team. At the same time, the architectures were conceived according to the canons of modernity (Caniggia 1959).

First of all, the Campus is exemplary because it presents itself "as a closed element of a city by parts" (Muntoni 2010, p. 95). It is a singular set-up inspired by medieval walled cities and deeply rooted in Piacentini's urbanistic repertoire.

The general plan, indeed, was drawn up by Piacentini as a composition of differentiated buildings located around a central square of the same size as Navona Square.

The layout is reminiscent of a basilica with an ample space devoted to the transept, whose major side is occupied by the Rector's House designed by Piacentini himself and by the institutes of Letters and Law assigned to Rapisardi. The citadel is encircled by walls with the intention to isolate it and make it independent from the nearby neighborhood of San Lorenzo and the Verano Cemetery. The second relevant aspect is the requirement of architectural unity that Piacentini imposed in accordance with Mussolini. The directions concerned some compositional aspects-floor heights, window shapes, flat covers-together with materials and technologies obviously linked to the autarchic policies.

However, Piacentini's guidelines left some freedom to the various architects in the design of the single buildings. Therefore, the architectural theme was developed as a compromise between monumentalism, rational design, and experimentation with new materials (Azzaro 2012), and different styles of Italian modernity coexist in relation to autarchic conditions.

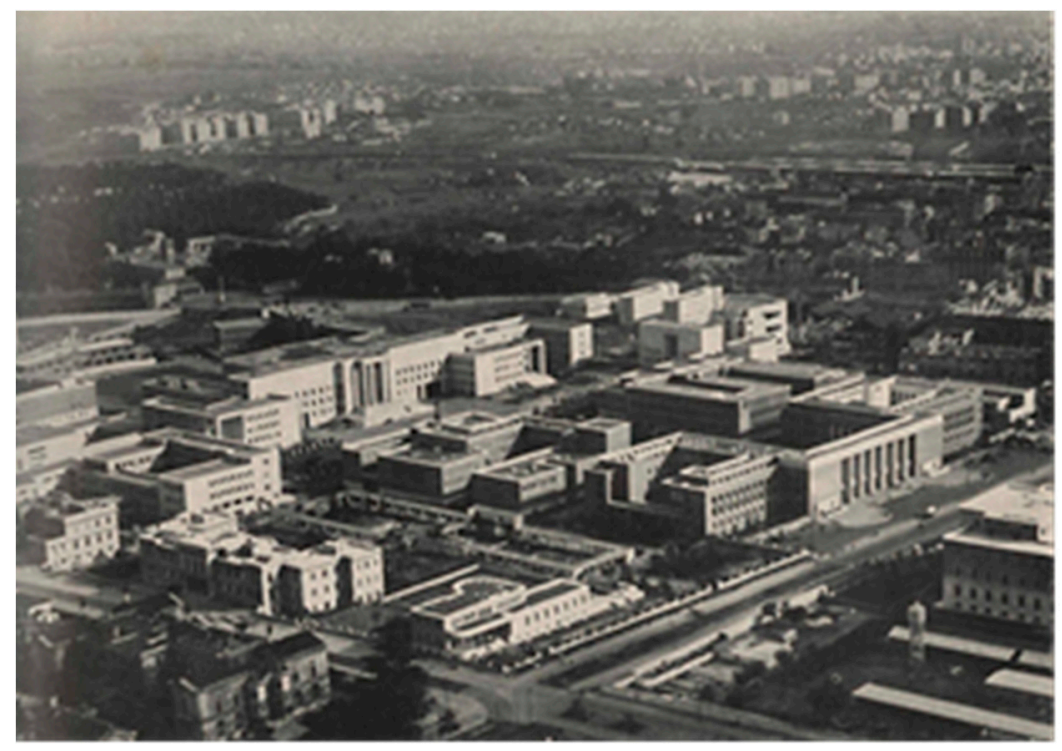

Figure 27. The campus of Sapienza University of Rome (1993-1935). Photo from (Baliviera et al. 1935, p. 5).

The extremes of this delicate balance are represented on one side by the Rectorate of Piacentini and on the other by the Giuseppe Capponi Institute of Botany (Figures 28 and 29). The plastic play of the blocks and the large angular windows of the Capponi Institute contrast with the rhetorical facade of the Rectorate and its monumental portico. Another important building is the Gio Ponti School of 
Mathematics. Composed of three volumes-a parellalepid, two curved wings, and the amphitheater tower-it presents on the main front a large rectangular window, a modernist interpretation of a triumphal arch (Figures 30 and 31). The compromise between tradition and innovation is reflected in the repertoire of materials and techniques used in balance between craftsmanship and industrial culture. The plan involved common construction design-plasters, cladding in Travertine, regional stones or Litoceramica, various types of rectangular windows, innovative glasses such as Termolux, frames, jambs, and thresholds in stone blocks, rational interiors, and a system of furnishings still in use today (desks, chairs, armchairs, lighting equipment, cabinets, coat hangers, handles). All of the buildings, from the foundations to the interiors of each office, hall, and classroom, were furnished by specialized Italian companies, from iron frames to scientific instruments and so on (Dal Falco 2017, pp. 28-35). Compared to the architecture, the modernity of the furnishings appears more linear, and the typologies incorporate functional models with tubular steel structures.

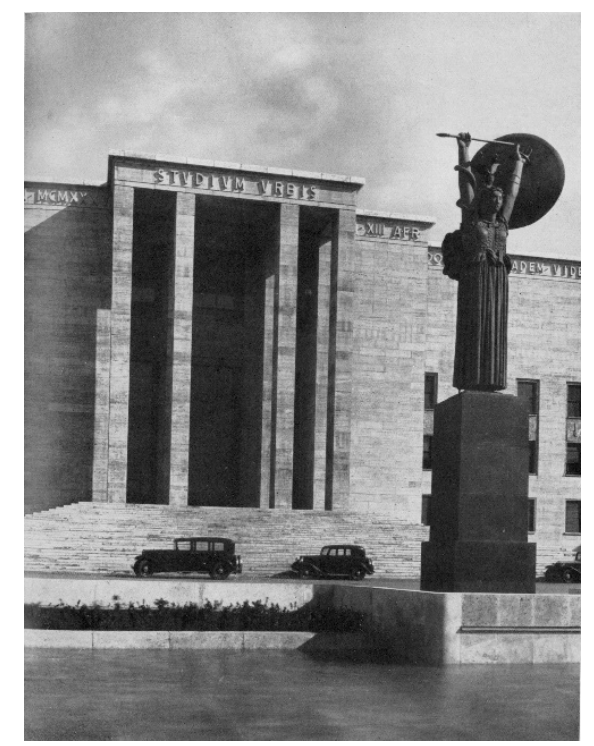

Figure 28. The Rectorate by Marcello Piacentini. Photo from (Baliviera et al. 1935, p. 9).

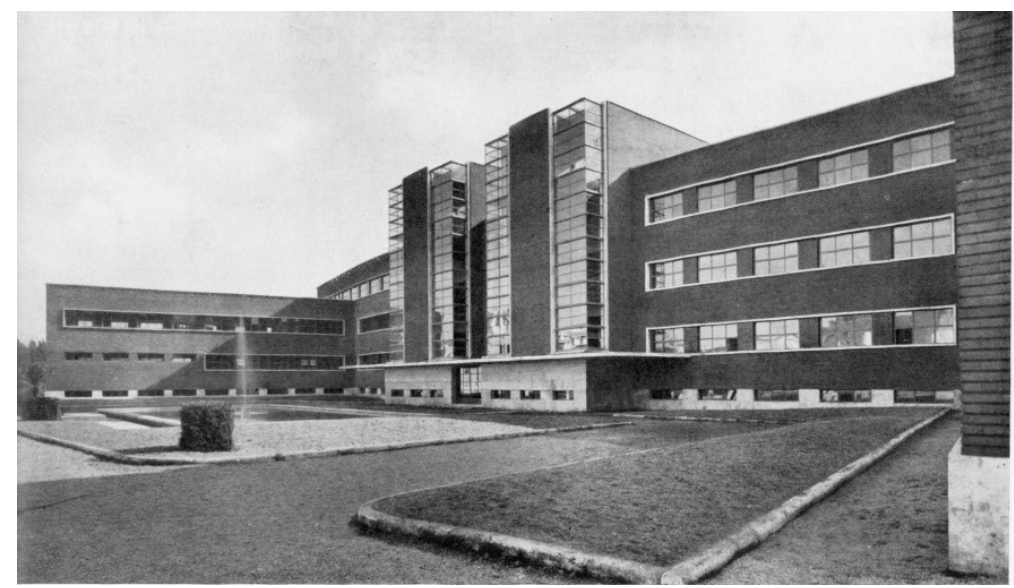

Figure 29. The Institute of Botany by Giuseppe Capponi. Photo from (Baliviera et al. 1935, p. 65). 


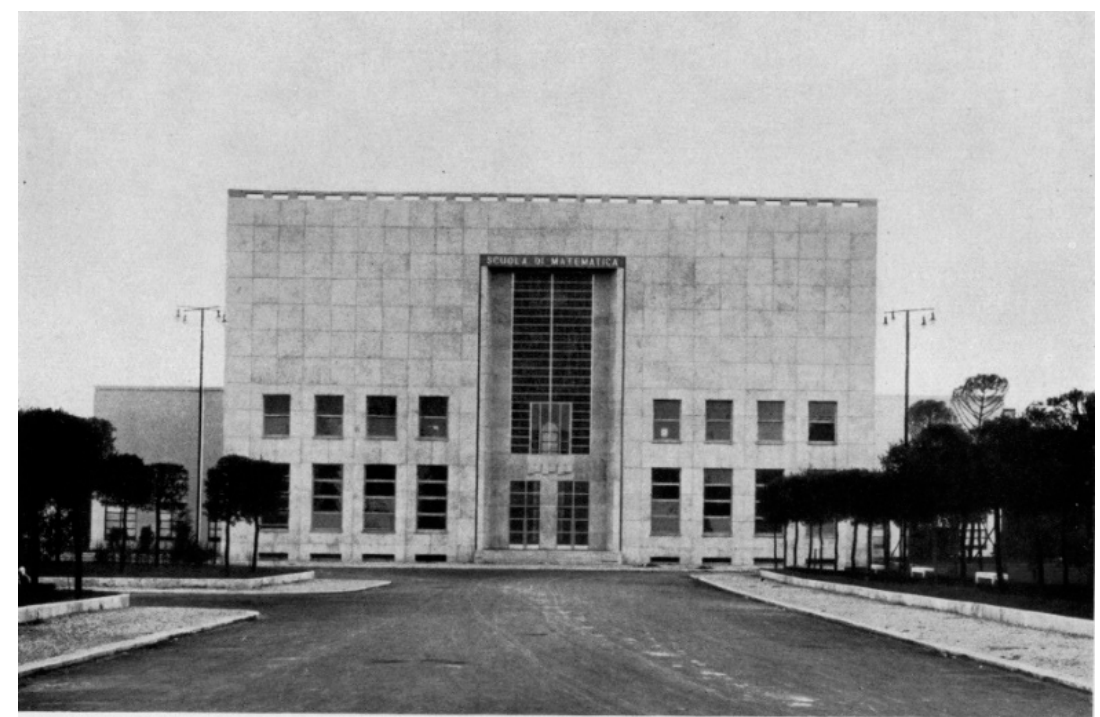

Figure 30. School of Matematics by Gio Ponti (1933-1935). Photo from (Baliviera et al. 1935, p. 45-46).
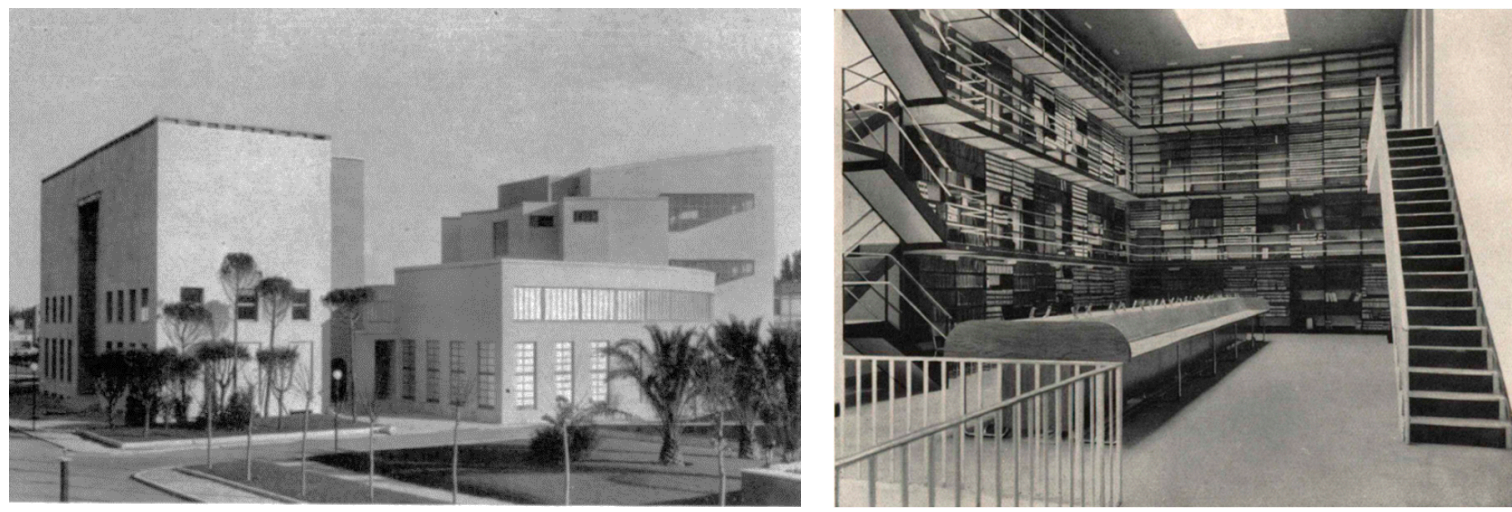

Figure 31. School of Matematics by Gio Ponti (1933-1935). The library. The floor is of green linoleum.

The shelving and stairs are in red painted iron. Photo from (Baliviera et al. 1935, p. 47).

\subsection{The Institute of Physics by Giuseppe Pagano Pogatschnig: Architecture and Design}

One of the most interesting buildings of Rome's University campus is the Institute of Physics designed by Giuseppe Pagano Pogatschnig (1896-1945). Pagano was one of the main protagonists of the modern renewal of architecture and design in the 1930s.

In opposition to the monumentalism and the academic rhetoric of the fascist regime, this architect viewed architecture as socially engaged, open to the new needs brought about by the industrialization process (Bassi and Castagno 1994; Bassi 2014; Melograni 1955; De Seta 1976; Saggio 1984).

Pagano distanced himself from the regime and went underground in the 1940s. In the memory of the art critic Carlo Ludovico Ragghianti, who met him at the beginning of October 1943, Pagano was the soul of Carrara's armed patriots and led the partisan fight in Tuscany. Shortly after, he was captured and deported. Pagano died in Mauthausen, assassinated by the Nazis.

Thus, beside being an architect, he had a critical spirit and was a man of action motivated by generous sentiments and deep social concerns.

Also in the 1930s, his cultural standpoint was such that he always aimed at contrasting reactionary academicism, an attitude that is reflected in his entire critical and projectual work. The project principles followed by Pagano were inspired in simplicity, clarity, functionality, and experimentation of products and innovative technologies, taking for granted the relationship with classicism. 
To the latter, indeed, he traced back the standardization, comparing it to the rhythm in architecture, a very ancient principle of repetition in the space of ordered forms or decorative elements (Pagano Pogatschnig 1933).

According to Argan (1946), Pagano's concept of standard was based on a unique principle-the adherence of architecture and design to man's needs must be such that the designer can think of forms only as they are directly thought by the community.

Beside his project activities, Pagano was co-director of the journal Casabella, joining the critic Edoardo Persico since 1931, and author of essays on architecture and new materials. His publishing activity is very important in order to understand Pagano's sensibility to the technological issue, an interest originated in the early days of his career. Ranging from architecture to design, Pagano outlined his own style by always using practical and cheap advanced materials in the name of what was called "rhetoric of simplicity". His global approach is apparent in the three buildings that he built from 1928 through the following fourteen years, the offices of the Gualino Palace in Turin (1928-1932) that was mentioned in Section 2.1, the Institute of Physics, and the subsequent Commercial University Bocconi of Milan in collaboration with Giangiacono Predeval (1937-1942) (Figures 32-34).

In all three buildings, Pagano designed the interiors and furnishings, also making use of the standard production on the market. His activity as a designer was characterized by a strong interest in standard furniture, in particular for metal furniture, and it extended to the field of transportation design with studies for aerodynamic lines and interior design of the ETR200 (Elettro Treno Rapido) Breda, the progenitor of Italian high-speed trains. Pagano was the curator of the 1940 Milan Triennale Exhibition that was entirely devoted to industrial design (Bassi 2014).

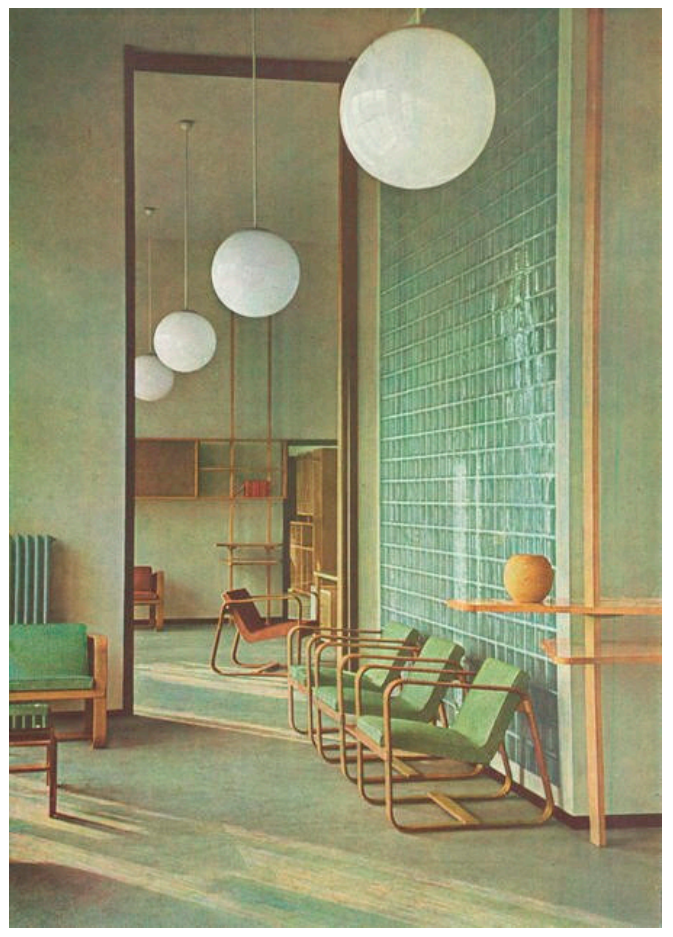

Figure 32. Commercial University Bocconi by Giuseppe Pagano Pogatschnig and Giangiacomo Predeval. Milan (1937-1942). Passage between the Rector's study and the director's office. Photo from Domus (1942). 


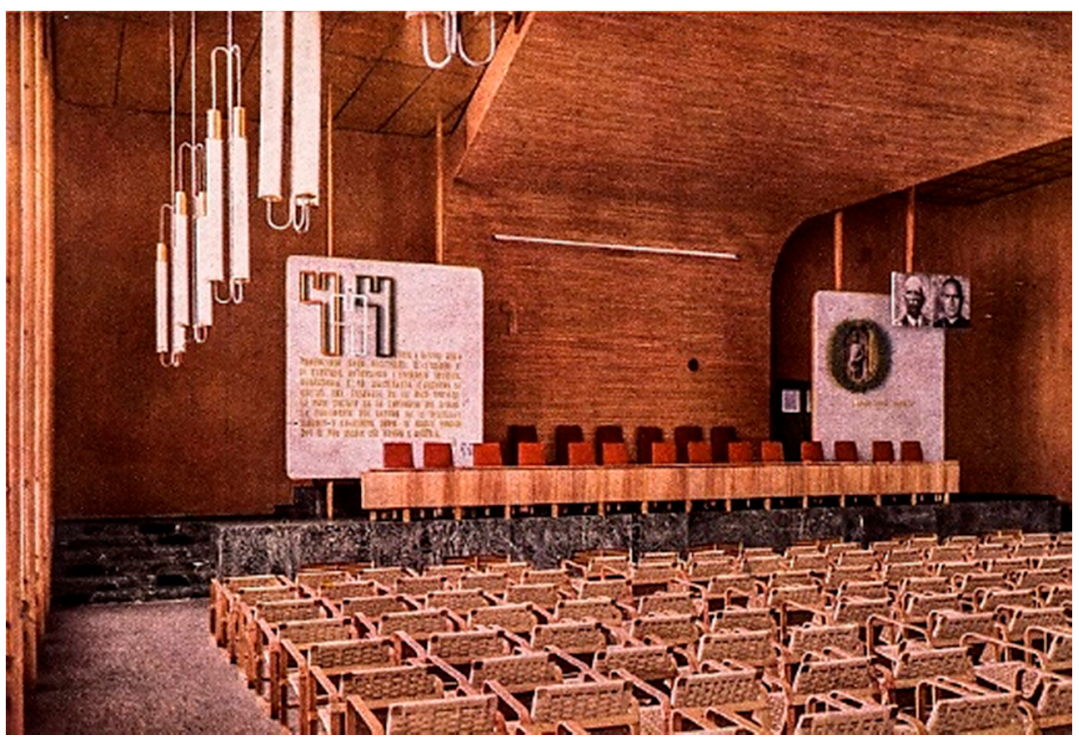

Figure 33. The auditorium with armchairs in curved plywood. Patent of the Maggioni company in Varedo. From: Università Bocconi di Milano. Costruzioni Casabella 170-171: allegato 59.

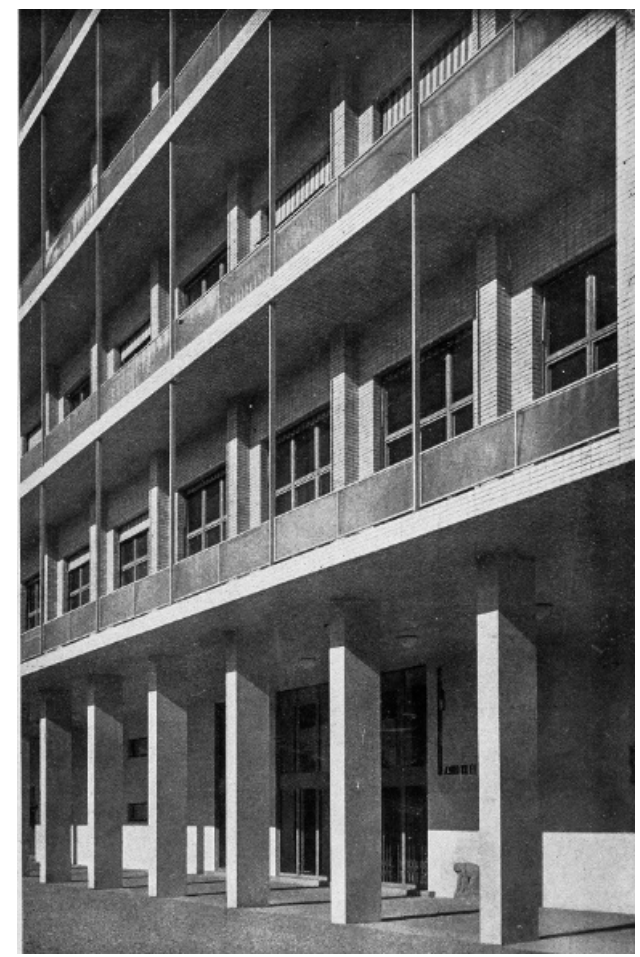

Figure 34. The block of offices. Lithoceramic coating, wooden window frames, parapets in safety glass. Photo from (Pagano Pogatschnig 1942, p. 7).

In the two university buildings, particularly in the more mature Bocconi Univerisity (Pagano Pogatschnig 1942, pp. 2-4) Pagano's passion for the new materials-stoneware, glass block, linoleum, steel-was pushed to the extreme with sophisticated chromatic research on the shades of green and grey.

Another interest always present in his work is the integration of architecture and art, of which the works by Arturo Martini and the pottery by Fausto Melotti and Tullio d'Albissola in the Milan's building are good examples (Bassi and Castagno 1994, p. 113). 
The close ties linking the two university architectures concern both the aspects specific to the architectural composition and those inherent to the construction choices, the materials, and the furnishings.

As Alessandra Muntoni writes (Muntoni 2010, p. 104), the architecture of the Institute of Physics is cultured and inspired by different European models, such as Gropius' Bauhaus, Marinus Dudok's Dutch Pavilion in Paris' Cité Internationale Universitaire, Gunnar Asplund's library in Stockholm (Figures 35-38).

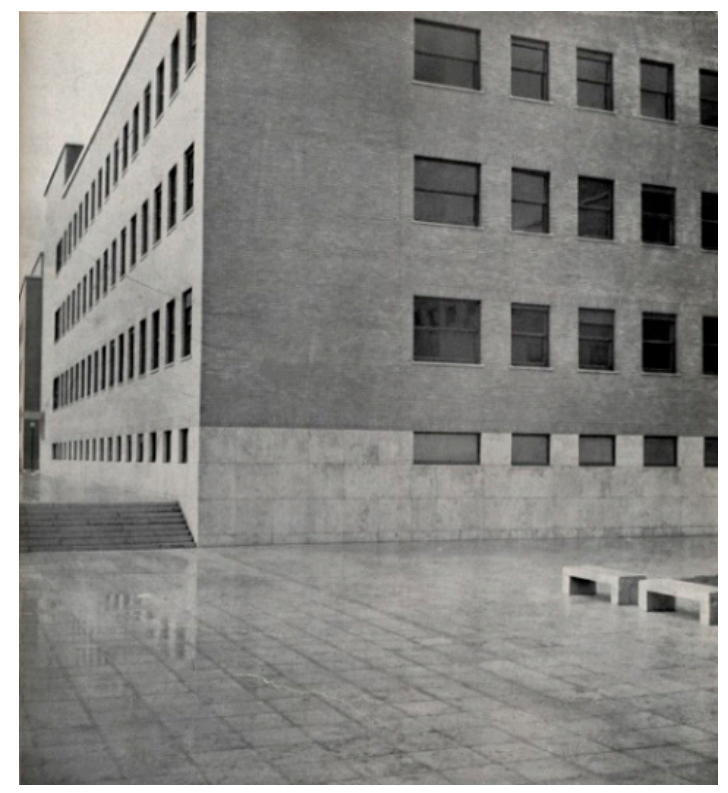

Figure 35. Institute of Physics by Giuseppe Pagano Pogatschnig (1932-1935). Particular of the coating in Litoceramica and of the external floor of travertine. The benches are three blocks of travertine. Photo from (De Smaele 1936, p. 11).

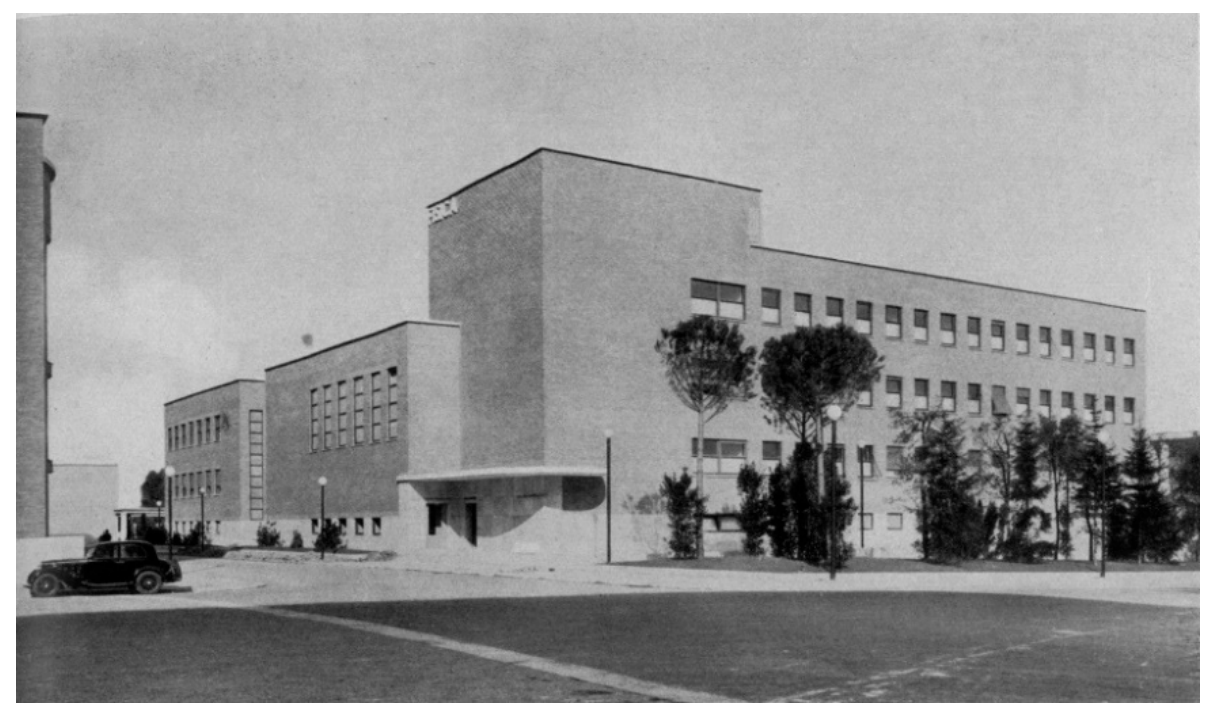

Figure 36. A corner view of the complex. Photo from (De Smaele 1936, p. 10). 


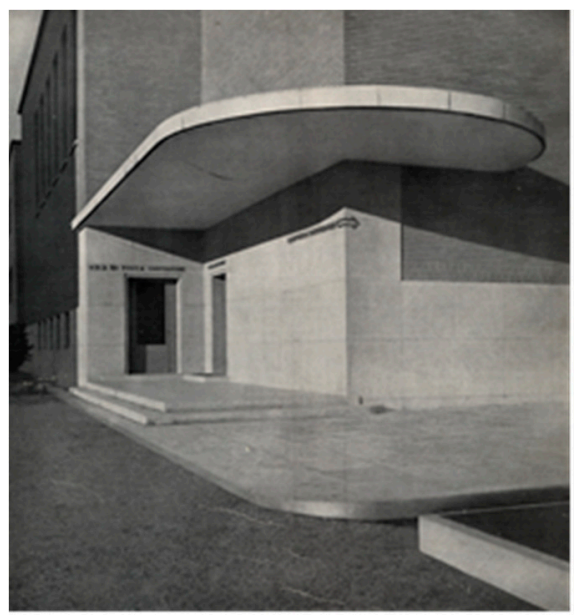

Figure 37. The side entrance to the classrooms. Photo from (Papini 1936, p. 5).

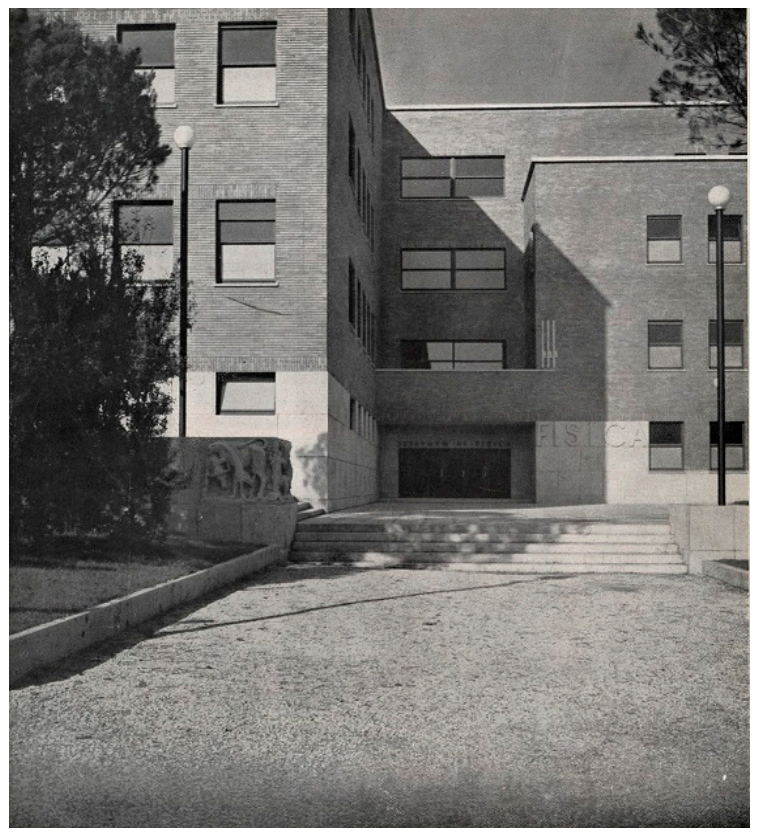

Figure 38. The main entrance. Photo from (De Smaele 1936, p. 9).

The descriptions and the photographic images of the Institute of Physics published by Casabella in 1936 provide a rich documentation of the architectural project and the furnishings utilized in the classrooms, the laboratories, and the hall. Pagano carefully studied any architectonic detail, including doors and windows; he designed various types of furniture manufactured in series, and he used seats made by metallic tubular and metallic bookshelves made by Lips Vago (Bassi and Castagno 1994, p. 103).

The care with which Pagano chose and approached the materials and drew all the elements and construction systems was instrumental in solving problems of environmental comfort and achieving optimal functioning. From the constructive point of view, the Institute of Physics is exemplary for its particular technological mix.

The building walls, which develop around a courtyard, are in load-bearing masonry $60 \mathrm{~cm}$ thick. The beams are made of reinforced concrete, the floors of mixed type, and the roofs are flat and practicable. The walls are coated with yellow-orange Litoceramica bricks, while the Travertine is used in blocks for the base and in square slabs of $60 \mathrm{~cm}$ for the square on which the main entrance opens (Pagano Pogatschnig 1936). The simplicity and rigor of the Institute are exemplified by the careful design of the rectangular windows. 
Pagano drew two types of wood frames that were manufactured by the company Fratelli Villa of Telesforo and Antonio. The frames present the same shape, size, and materials, but they differ in the closing system. Most of the windows measure $150 \times 200 \mathrm{~cm}$ and are subdivided by two identical larch frames, which have a flap and latch opening. The Victoria patent allows the sliding up and down of the two doors and the flap opening of the lower frame equipped with an insulating glass and a Termolux diffuser.

In the interior, Pagano used a green linoleum shade for the surfaces. The same material and color was adopted for the floorings apart from the Carrara marble paving utilized for atriums, staircases, and landings (Pagano Pogatschnig 1936). The green color was also used by Pagano for the vertical finishes in enamel and paint. The walls of the Superior and Experimental Physics graduated classroom are covered with green Richard-Ginori ceramics on which the equipment was installed, including sliding boards, paintings, ammeters, clocks, and voltmeters (Figure 39). Additionally, the laboratories were designed with innovative materials, always with linoleum floors and metal furniture (Figure 40). The furniture was particularly studied by Pagano. Archive sources and architecture magazines of the period prove that the office furniture was directly conceived by the architect. The project consisted of forty types including chairs, desks, paper holders, and metal sheet cabinets that differed from each other for the variation of shelves thickness and distribution. From the photographs and the documents conserved in the Sapienza University Historical Archives-in particular in the C.E.R.U.R. Fund (Consorzio per l'assetto edilizio della Regia Università di Roma)-we can see that the office type was designed in a linear way and furnished with metallic furniture. The table $(250 \mathrm{~cm} \times 80 \mathrm{~cm})$ could have the top covered in green or black linoleum, in $5 \mathrm{~mm}$ pressed masonite, or in pitch pine.

The base consisted of two cabinets that could be made with different variants with or without drawers. Chairs and armchairs presented tubular steel structures and wooden seats. A model with padding was also made (Figures 41 and 42). The furniture was manufactured by the Parma company of Saronno (Figure 43). Then, there was the delicate question of the classroom desks. In line with the functional, essential, and practical approach that characterized his design concept, Pagano posed two problems, the ergonomic question and the maximum exploitation of the space with a minimum encumbrance.

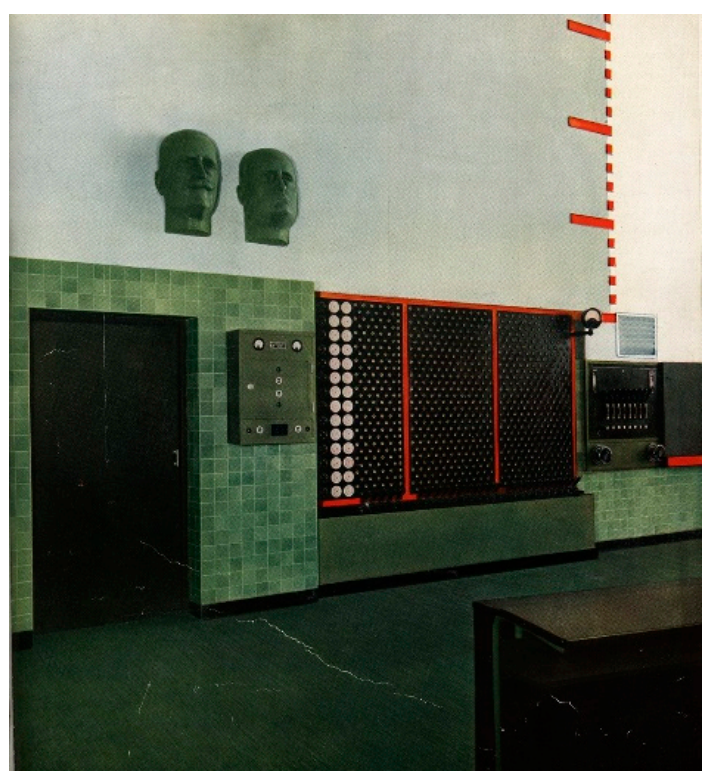

Figure 39. The Superior and Experimental Physics graduated classroom. Photo from (De Smaele 1936, p. 21). 


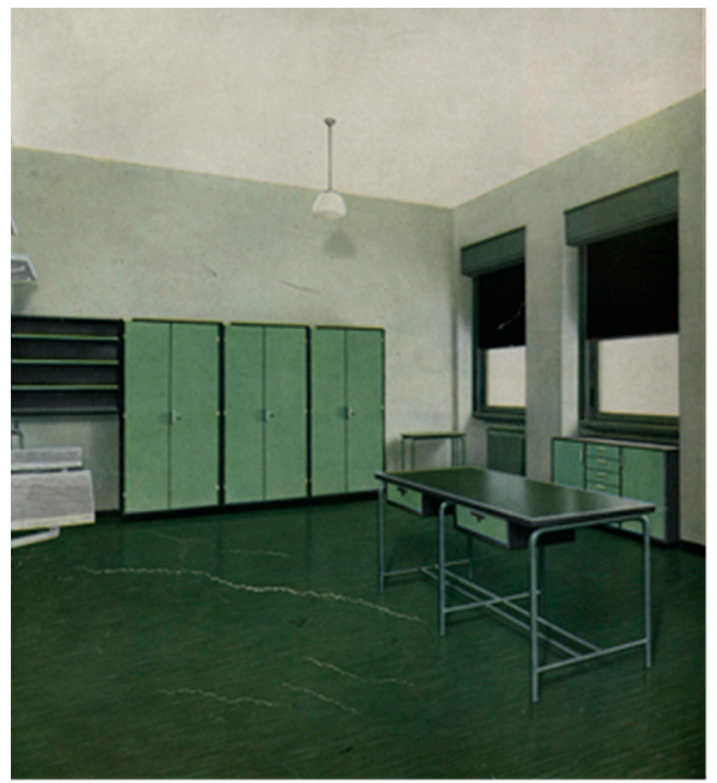

Figure 40. The laboratories with the furniture designed by Pagano. Photo from (De Smaele 1936, p. 25).

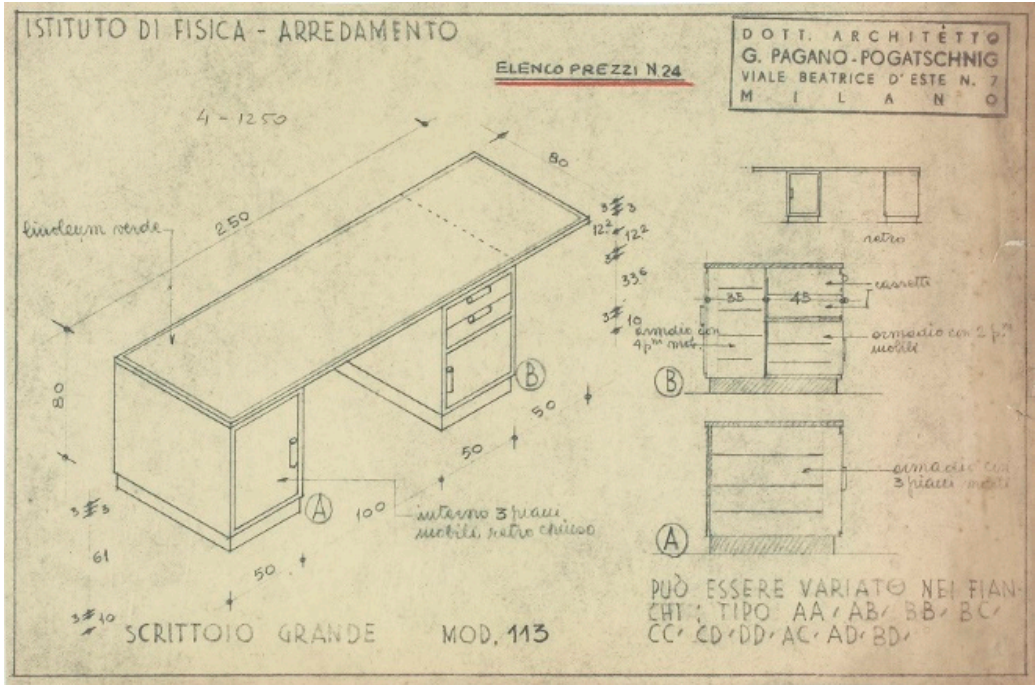

Figure 41. Drawing by Giuseppe Pagano. Office table. Image from: C.E.R.U.R. Fund (Consorzio per l'assetto edilizio della Regia Università di Roma) Envelope 32, Pos 88.
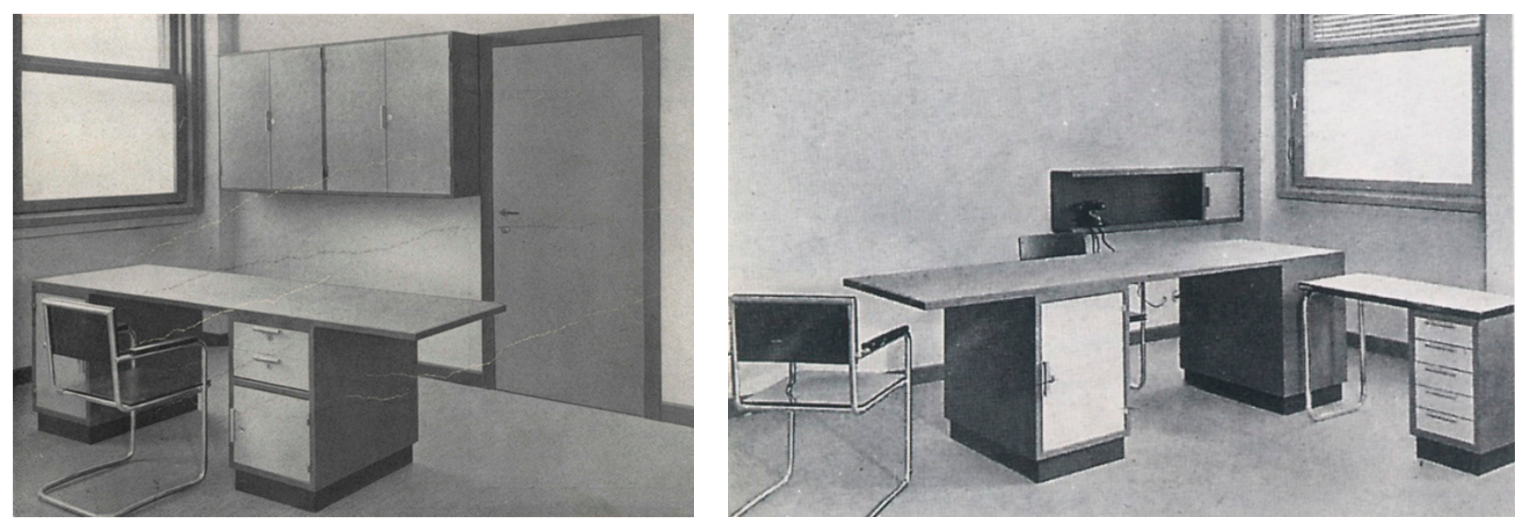

Figure 42. Institute of Physics. Type office. Photo from (De Smaele 1936, p. 24). 


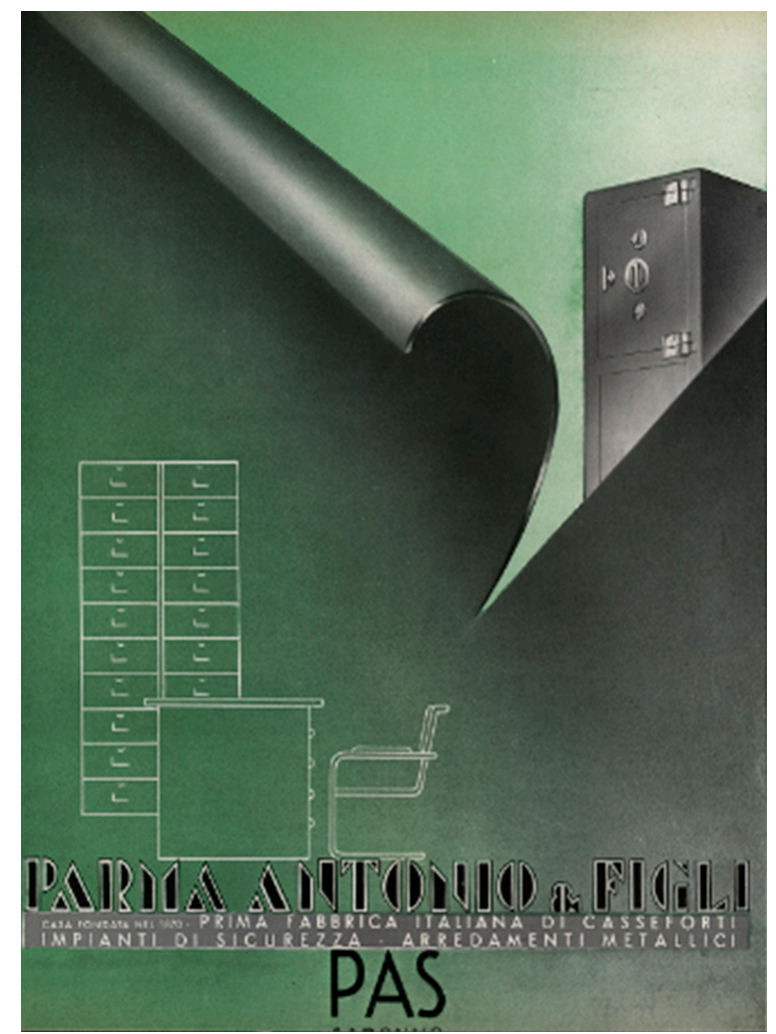

Figure 43. Advertising PAS (Parma Antonio \& Figli). Image from Domus (1936).

After long negotiations, the production of the desks was entrusted to Beltrami company (Mitrano 2008) (Figures 44-46). The company's choice of metal shelving for the library was also complex. Finally, the assignment was given to the Lips Vago (Figure 47).

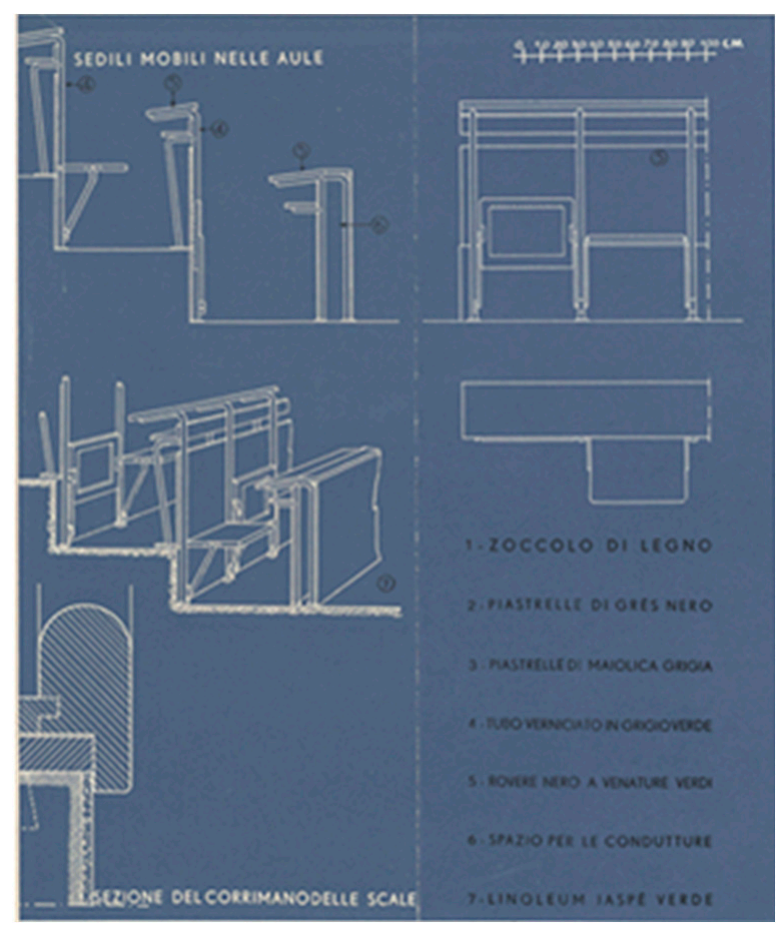

Figure 44. Technical drawing of articulated bench. Image from (De Smaele 1936, p. 20). 


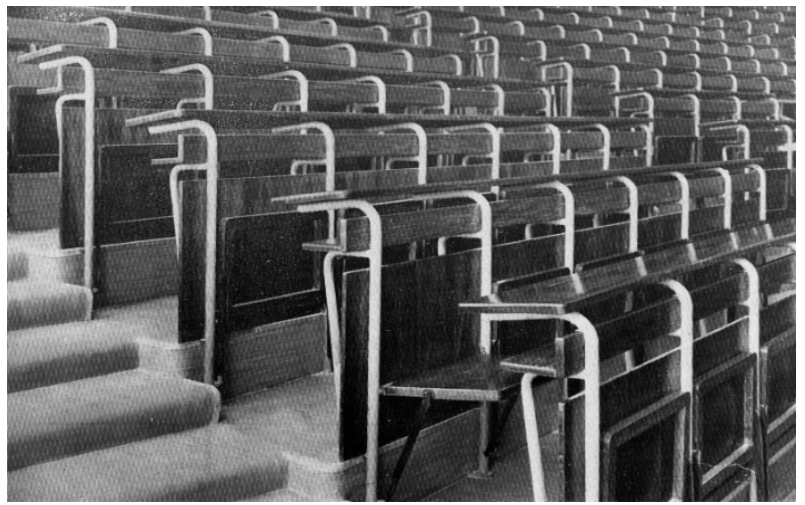

Figure 45. Institute of Physics. The classroom desks. Photo from (De Smaele 1936, p. 20).

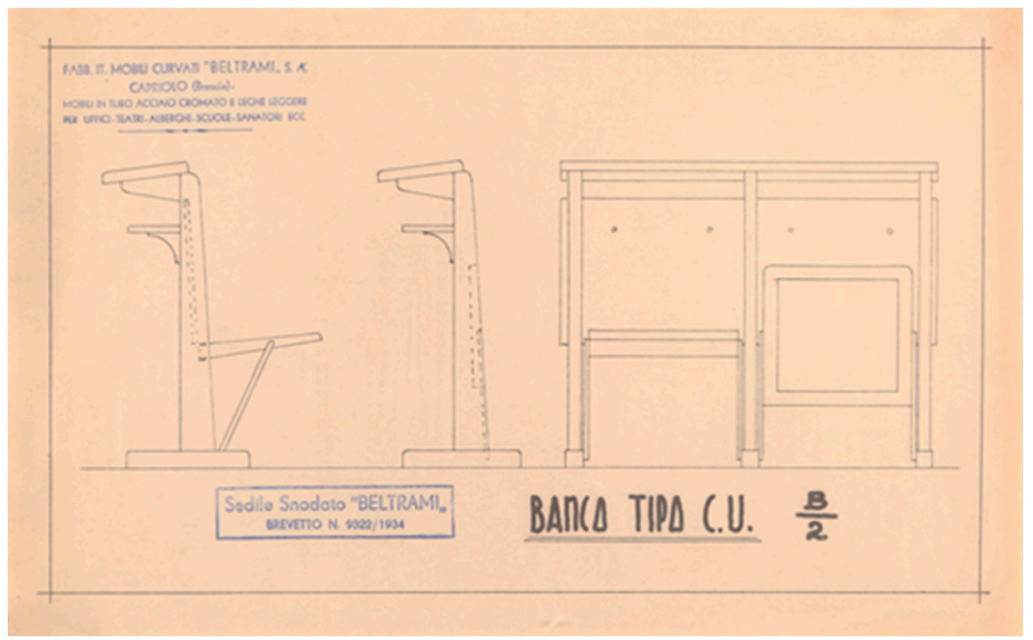

Figure 46. Technical drawing of articulated bench by Beltrami company. Patent 9322/1934. Image from: C.E.R.U.R. Fund (Consorzio per l'assetto edilizio della Regia Università di Roma) Envelope 43.
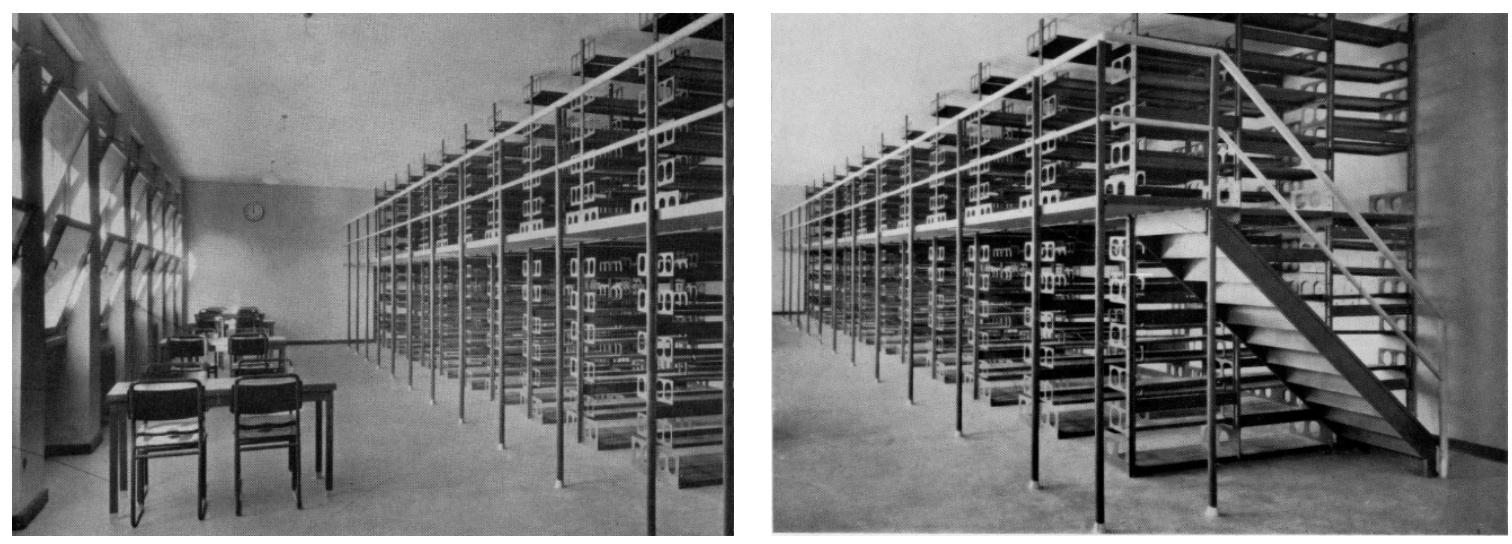

Figure 47. Institute of Physics. Metal shelving for Library. Photo from (De Smaele 1936, p. 23).

To conclude this paragraph, it is possible to affirm that the Physics Institute was a laboratory of modern architecture and design in which Pagano was able to interpret the programmatic lines outlined by Piacentini with exemplary research on environmental comfort and functionality.

This case opens a field of historical, morphological, and constructive investigation of scientific interest. The studies, combined with the idea of global design that underpins their realization, should be extended to the myriad of objects and furnishings that are still present today, producing many questions related to their knowledge and enhancement. 


\section{Conclusions}

As I tried to show, the peculiarity of the modern movement of Italian architecture that flourished in the period of 1926-1943 lies in a singular synthesis between national tradition and international avant-gardes, an expression of rationalism rooted in the history of architecture and conditioned by the politics of the fascist regime. Consistently, the uniqueness of modern Italian architecture can be identified in its double link with the forms of the past and urban stratifications and with the principles of the modern movement.

The analysis outlined here covers the main topics of the influence of autarchic politics in architecture and design, the new profile of the integral architect connected to the foundation of the School of Architecture in Rome, the main architectural themes, the collaborations between rationalist architects, and industries with the testing of new standardized typologies of objects.

The technological question is considered central and shows how Italian rationalism is characterized by some common themes associated with the characteristics of new materials and constructive procedures.

The new vision prevailing in Italy in the interwar period manifested itself through the integration between architecture and industrial production. This integrated approach led to a reflection on the modalities whereby industrial production could influence and renew the architectural culture.

The integration of these two fields was due to several factors including the evolution of schools, academies, and institutes where-beginning in the early 1920s-a convergence between them took place, the creation of specialized magazines (Architecture and Decorative Arts in 1921, La Casa Bella and Domus both founded in 1928), and above all, the temporary exhibitions of the Monza Biennial (1923, 1925, 1927, 1930) and of the Milan Triennial (1933-1940) where furnishings became more connected to serial production (Guida 2017; Morone 2017).

It is evident how the culture of the rationalist project involving architecture and design was strongly conditioned by the new materials and technologies necessary to permit the evolutionary leap that placed these artifacts in the scenario of modernity comparable with what was achieved abroad. For instance, the interest in metal furniture linked the Italian designers of that time to their Bauhaus counterparts such as Marcel Breuer, whose iconic metal furniture produced in Germany was known by Giuseppe Pagano.

In general, one could say that it was the design of the products of industrial civilization that gave rise to the new architecture (Bassi and Castagno 1994, p. 79). The case study of the Institute of Physics by Giuseppe Pagano (and all of his work in general) substantiates this assertion, and it is exemplary in defining the integral approach to the project typical of modernity. An approach that, for Pagano, relied also to environmental problems and the functionality of the building and furnishings.

In this sense, modern architecture and design can be studied together through cataloguing, census, and comparison in order to transfer knowledge to future generations.

Also, in the methodological approach to the maintenance and restoration, many elements are closely intertwined, in particular those concerning the industrial components which are mostly out of the market today.

This article refers to an area of research related to the theme of restoration and redevelopment of modern architecture and design. The premise is that any maintenance, restoration, or redevelopment requires the understanding of the meanings of buildings and objects, including materials and technologies. The question is delicate and complex. The studies conducted for decades have identified some intervention methodologies that synthetically refer to two models.

The conservative model is applicable when the "original material" is strongly present in a limited number of exemplary cases (Carbonara 1992, p. 53). It is an orientation that follows the concept of "philological reconstruction", à l'identique, which provides transformations, although marginal ones.

This standpoint is founded on the concept of "critical restoration" and the restoration theory by Cesare Brandi. For Brandi, restoration is "the methodological moment of the recognition of the work 
of art in its physical and material consistency and in its aesthetic and historical polarity, in view of its transmission to the future" (Brandi 1963).

The second model is aimed at architectural redevelopment and contemplates greater degrees of freedom in intervening. However, the interventions are assessed "case by case" and must be based on historical and critical analysis.

The case study presented here-like other interesting buildings of the Rome University Campus such as the Gio Ponti's School of Mathematics-deserves research on the current state of the interior and a census of the original furnishings.

The goal is to recover the systems of objects still in use through a philological restoration that can give back its unity to an architecture that was conceived by Pagano in every detail.

Obviously, such restoration of buildings that are still utilized should update the features and equipment that are today obsolete but are necessary for environmental comfort and scientific laboratories.

One may conclude from what is discussed above that, while keeping one's distance from the fascist ideology and condemning it, autarky can be studied in an objective way in order to know and communicate constructive aspects of cities, architectures, and objects that participate in defining memories and habitats of past historical conditions and related social practices.

\section{Notes}

1. Among the prominent scientists who collaborated with the CNR (National Research Council) are the two chemists and academics Giulio Natta (1903-1979) and Livio Cambi (1885-1968). Natta, Nobel Prize winner for chemistry with Karl Ziegler in 1963 for "their discoveries in the field of polymer chemistry and technology", worked in the field of catalytic synthesis of alcohols and their derivatives, while Livio Cambi (1885-1968) dedicated his research to non-ferrous metals, contributing to building a cultural climate aimed at achieving national autonomy (Maiocchi 2003).

2. Italian territorial expansion reached its maximum extension at the beginning of the Second World War. The territories included parts of southern France, Dalmatia, Croatia, Montenegro, Albania, Greece, the Aegean islands, Eritrea, Somalia, Libya, Ethiopia, the Tianjin Chinese concessions, Shangai, and Amoy. At the end of the Second World War, harsh conditions were imposed on Italy with confiscation of territories including all of the colonies. Only Somalia was administered by an Italian mandate until 1960 (Rodogno 2006).

3. The frame was also used to build open spans: the portico of the Bocconi University offices (Milan, 1937-1942) by Giuseppe Pagano; the basement of the Palazzo delle poste (Rome, 1933-1935) by Alberto Samonà, the large windows towards the courtyard of the School of Mathematics (Città Universitaria di Roma, 1933-1935) by Gio Ponti; the windows of the main entrance of the Palazzo delle poste (Rome, 1933-1935) by Mario Ridolfi; some parts of the Youth House in Trastevere (Rome, 1932-1937) by Luigi Moretti, where the space between the pillars is closed by large windows divided by metal profiles (Dal Falco 2002, pp. 1-9).

4. An exemplary case of the use of glass-blocking, in particular of the "Nevada" model produced by the French company Saint-Gobain since 1928, is the Maison de Verre (1928-1932), which was built in Paris between 1928 and 1932 by Pierre Chareau and Bernard Bijvoet (Vellay and Frampton 1984).

Funding: This research received no external funding.

Acknowledgments: All translations by the author. All images are public domain or are taken from books that are electronically available as public domain.

Conflicts of Interest: The author declares no conflict of interest.

\section{References}

Abram, Sara, ed. 2014. The Conservation of Design. Reflections and Experiences on the Study and Preservation Project of the Historical Collection of the Compasso d'Oro Award. Torino: Allemandi \& Co. 
Anselmi, Anselmo, Mario Marcazan, and Marcelletti Mario. 1938. Autarchia. In Enciclopedia Italiana Treccani. (I Appendice). Available online: http:/ / www.treccani.it/enciclopedia/autarchia_(Enciclopedia-Italiana)/ (accessed on 7 January 2019).

Ardissone, dell'ILVA. 1936. Risposte di industriali all'articolo Battaglia da ingaggiare. Domus 102: 45.

Argan, Giulio Carlo. 1946. Valore di una polemica (Giuseppe Pagano). Costruzioni Casabella 195-198: 28-29.

Arrigotti, Enrico, G. Bardi, Carlo Belli, Mario Radice, Alberto Sartoris, and Giuseppe Terragni. 1936. Documentario sulla Casa del Fascio di Como. Quadrante 35-36: 52-56.

Artioli, Alberto. 1989. Giuseppe Terragni. La Casa del Fascio di Como. Guida critica all'edificio. Descrizione, Vicende Storiche, Polemiche, Recenti Restauri. Roma: Betagamma.

Ascione, Paola. 2017. Isolanti. Prodotto e applicazioni. In Materiali del Moderno. Campi, temi e modi del progetto di riqualificazione. Edited by Luciano Cupelloni. Roma: Gangemi Editore, pp. 330-35.

Azzaro, Bartolomeo. 2012. La città universitaria della Sapienza di Roma e le sedi esterne 1907-1932. Roma: Gangemi Editore.

Baliviera, Mario, Pietro De Francisci, Francesco Guidi, and Marcello Piacentini. 1935. La città univesitaria di Roma. Numero speciale. Architettura XIV.

Bassi, Alberto. 1988. A Chair is made for sitting on. Rational furniture manufactured by Columbus. In Flexible splendors. Tubular Furniture Metal. The Columbus Case. Edited by Anty Pansera. Milano: Electa, pp. 150-213.

Bassi, Alberto. 2014. Giuseppe Pagano's “Mostra internazionale della produzione in serie” (VII triennale, 1940): Framework and preparation of italy's first design exhibition. AIS/Design. Storia e ricerche 3. Available online: http:/ / www.aisdesign.org/aisd/rivista (accessed on 7 January 2019).

Bassi, Alberto, and Laura Castagno. 1994. Giuseppe Pagano Designer. Roma: Laterza.

Bernardini, Virginia. 2017. Litoceramica. In Materiali del Moderno. Campi, temi e modi del progetto di riqualificazione. Edited by Luciano Cupelloni. Roma: Gangemi Editore, pp. 146-50.

Bernardini, Virginia. 2017. Mosaico. In Materiali del Moderno. Campi, temi e modi del progetto di riqualificazione. Edited by Luciano Cupelloni. Roma: Gangemi Editore, pp. 159-72.

Bernardini, Virginia, and Federica Dal Falco. 1992. Manualistica: Architetture moderne. Tecniche, materiali, criteri progettuali. AU Tecnologie 8-9: 105-34.

Bosia, Daniela. 2017. Linoleum. In Materiali del Moderno. Campi, temi e modi del progetto di riqualificazione. Edited by Luciano Cupelloni. Roma: Gangemi Editore, pp. 368-79.

Brandi, Cesare. 1963. Teoria del restauro. Torino: Einaudi.

Caniggia, Gianfranco. 1959. Il clima architettonico romano e la Città universitaria. La Casa 6: 272-99.

Capitanucci, Gabriella. 2017. Buxus. Progetto e restauro. In Materiali del Moderno. Campi, temi e modi del progetto di riqualificazione. Edited by Luciano Cupelloni. Roma: Gangemi Editore, pp. 350-51.

Carbonara, Giovanni. 1992. Il restauro del nuovo e il caso del Weißenhof di Stoccarda. In Costruire Abitare. Gli edifici e gli arredi per la Weissenhofsiedlung di Stoccarda. "Bau und Wohnung" e "Innenräume" (1927-1928). Edited by Antonio Alfani, Giovanni Carbonara, Franca Pinci and Carlo Severati. Roma: Edizioni Kappa, pp. 49-60.

Castagno, Laura. 1994. Pagano e i meccanismi di formazione della modernità in Italia alla fine degli anni Venti. In Giuseppe Pagano Designer. Edited by Alberto Bassi and Laura Castagno. Roma-Bari: Laterza.

Cederna, Antonio. 1979. Mussolini urbanista. Lo sventramento di Roma negli anni del consenso. Bari: Laterza.

Chessa, Gigi. 1930. La nuova costruzione moderna per uffici in Torino, sul corso Vittorio Emanuele architettata da G. Pagano Pogatschnig e G. Levi Montalcini. Domus 6: 21-22.

Ciucci, Giorgio. 2002. Gli architetti e il fascismo. Architettura e città 1922-1944. Torino: Einaudi Editore.

Cohen, Jean-Louis. 2012. Architecture en uniforme. Projeter et construire dans la seconde guerre mondiale. Paris: Editions Hazan.

Crachi, Piercarlo. 1997. Patents on Tubular Metal Furniture in Italy and Switzerland between the Two World Wars. In Flexible Splendors. Tubular Furniture Metal. The Columbus Case. Edited by Anty Pansera. Milano: Electa, pp. 52-65.

Crespi, Raffaella. 1987. Giuseppe Terragni Designer. Milano: Franco Angeli editore.

Cupelloni, Luciano. 2017. Isolanti. In Materiali del Moderno. Campi, temi e modi del progetto di riqualificazione. Edited by Luciano Cupelloni. Roma: Gangemi Editore, pp. 328-29.

Cupelloni, Luciano. 2017. Ri-qualificare il moderno. Materiali, temi e modi. In Materiali del Moderno. Campi, temi e modi del progetto di riqualificazione. Edited by Luciano Cupelloni. Roma: Gangemi Editore, pp. 25-61.

D'Amato, Claudio. 2017. La Scuola di Architettura di Gustavo Giovannoni e la sua eredità oggi in Italia. Bollettino del Centro di Studi per la Storia dell'Architettura 1: 33-46. 
Dal Falco, Federica. 2002. Stili del Razionalismo. Anatomia di quattordici opere del Razionalismo italiano. Roma: Gangemi Editore.

Dal Falco, Federica. 2013. The importance of local resources in times of economic hardship. In Design, Crise e Depois-Design, Crisis and Aftermath. Edited by Raul Cunca, Isabel Dâmaso Rodrigues and Victor Almeida. Lisboa: Ediçao CIEBA, pp. 68-77.

Dal Falco, Federica. 2014. Prodotti autarchici 1930-1944. Architettura Design Moda. Roma: Rdesignpress.

Dal Falco, Federica. 2017. Il design integrale del Razionalismo italiano. Stili della cultura progettuale romana tra tradizione e modernità. Das integrale Design des italienischen Rationalismus. Projektkultur zwischen Tradition und Moderne. In Luoghi del moderno 1920-1950. Klares Bauen 1920-1950. Edited by Tiziano Rosani, Patrick Rina, Marina Mascher and Ulrike Kindl. Bolzano/Bozen: La Fabbrica del Tempo/Die Zeitfabrik, pp. 28-35.

Dal Falco, Federica. 2017. Marmo, granito, travertino. Prodotto e applicazioni. In Materiali del Moderno. Campi, temi e modi del progetto di riqualificazione. Edited by Luciano Cupelloni. Roma: Gangemi Editore, pp. 86-87.

Dal Falco, Federica. 2017. Metallo bianco. In Materiali del Moderno. Campi, temi e modi del progetto di riqualificazione. Edited by Luciano Cupelloni. Roma: Gangemi Editore, pp. 316-24.

Danesi, Silvia, and Luciano Patetta, eds. 1976. Il Razionalismo e l'architettura italiana durante il fascismo. Milano: Electa.

De Fusco, Renato. 2010. Made in Italy. Storia del Design Italiano. Roma: Laterza.

De Seta, Cesare, ed. 1976. Giuseppe Pagano. Architettura e città durante il fascismo. Roma: Laterza.

De Smaele, Enrico. 1936. Descrizione tecnica. Casabella 99: 8-25.

Diotallevi, Irenio, and Franco Marescotti. 1939. Presentazione tecnica della costruzione, degli impianti, dell'arredamento. Casabella-Costruzioni 138-40: 21-133.

Finessi, Beppe, ed. 2014. Il design italiano oltre le crisi. Autarchia, Austerità, Autoproduzione. Catalogo della Mostra. Triennale Design. Milano: Corraini Editore.

Garda, Emilia. 2017. Buxus. In Materiali del Moderno. Campi, temi e modi del progetto di riqualificazione. Edited by Luciano Cupelloni. Roma: Gangemi Editore, pp. 346-55.

Gentile, Emilio. 2002. Fascismo. Storia e interpretazione. Roma: Laterza.

Gentile, Emilio. 2007. Fascismo di pietra. Roma: Laterza.

Giardina, Andrea, Giovanni Sabatucci, and Vittorio Vidotto. 1988. Uomini e storia 3. Dall'Ottocento al Duemila. Roma: Laterza.

Gregotti, Vittorio. 1982. Il disegno del prodotto industriale. Italia 1860-1980. Milano: Electa.

Guida, Ermanno. 2017. Introduzione. In La Fabbrica dell'innovazione. Gli arredi del palazzo delle Poste. Napoli 1936. Edited by Alfonso Morone. Siracusa: Lettera Ventidue Edizioni srl, p. 20.

Guidi, Francesco. 1935. Caratteristiche tecniche e organizzazione esecutiva delle opere nella Città Universitaria. Architettura. fascicolo speciale XIV: 9-43.

Insolera, Italo. 1962. Roma moderna. Un secolo di storia urbanistica. 1870-1970. Torino: Einaudi.

Irace, Fulvio. 1977. Gio Ponti. La casa all'italiana. Milano: Electa.

Maiocchi, Roberto. 2003. Il ruolo dei ricercatori e del CNR nella politica autarchica del fascismo. Gli scienziati del duce. Roma: Carrocci.

Maiocchi, Roberto. 2013. L'Italia e l'autarchia. Il Contributo Italiano alla Storia del Pensiero-Tecnica. Available online: http:/ / www.treccani.it/enciclopedia/1-italia-e-1-autarchia_(Il-Contributo-italiano-alla-storia-delPensiero:-Tecnica)/ (accessed on 7 January 2019).

Mantero, Enrico, ed. 1984. Il razionalismo italiano. Bologna: Zanichelli.

Marchis, Virgilio. 1998. The Metal Tube, from mimesis to Invention. Technological artifacts vith a natural form. In Flexible Splendors. Tubular Furniture Metal. The Columbus Case. Edited by A. Pansera. Milano: Electa, pp. 12-25.

Marcianò, Ada Francesca. 1987. Giuseppe Terragni. Opera completa 1925-1943. Roma: Officina Edizioni.

Marconi, Plinio. 1937. La Casa delle Armi al Foro Mussolini in Roma. Architettura VIII: 437-54.

Marconi, Plinio. 1941. Casa della Gioventù Italiana del Littorio a Roma in Trastevere. Architettura IX-X: 361-73.

Marescotti, Franco. 1937. Le applicazioni del Linoleum. Casabella 109: 36-41.

Melograni, Carlo. 1955. Giuseppe Pagano. Milano: Il Balcone.

Melograni, Carlo. 2008. Architettura italiana sotto il fascismo. L'orgoglio della modestia contro la retorica monumentale 1926-1945. Torino: Bollati Boringhieri. 
Minnucci, Gaetano. 1933. Concorso nazionale per i palazzi postali di Roma. Architettura X: 603-26.

Mitrano, Ida. 2008. La Sapienza 1932-1935 arte architettura storia. Roma: Centro Stampa Università, Università Degli Studi di Roma La Sapienza.

Morone, Alfonso, ed. 2017. La Fabbrica dell'innovazione. Gli arredi del palazzo delle Poste. Napoli 1936. Siracusa: Lettera Ventidue Edizioni srl.

Muntoni, Alessandra. 2010. Roma tra le due guerre 1919-1944. Architettura, modelli urbani, linguaggi della modernità. Roma: Edizioni Kappa.

Mussolini, Benito. 1957. Il piano regolatore della nuova economia italiana. In Opera Omnia di Benito Mussolini. Edited by Edoardo Susmel and Duilio Susmel. Firenze: La Fenice, p. 241.

Nunzi, A. 1938. Il lavoro per l'autarchia nelle industrie del vetro e della ceramica. Il Vetro 6: 157-61.

Padoan, Alessandro, Palmaghini Alessandro, and Anty Pansera. 2018. Arredoluce. Catalogo ragionato. $1943-1987$. Milano: Silvana Editoriale.

Pagano Pogatschnig, Giuseppe. 1933. L'estetica delle costruzioni di acciaio. Casabella 8-9: 68-69.

Pagano Pogatschnig, Giuseppe. 1934. Il Buxus. Casabella 73: 48-51.

Pagano Pogatschnig, Giuseppe. 1936. L'Istituto di Fisica. Casabella 99: 6.

Pagano Pogatschnig, Giuseppe. 1938. Variazioni sull'autarchia architettonica II. Casabella Costruzioni 130: 2-3.

Pagano Pogatschnig, Giuseppe. 1942. La Nuova sede dell’Università commerciale Luigi Bocconi. Premessa. Costruzioni Casabella 170-171: 2-8.

Palazzo delle Feste, dei Congressi e dei Ricevimenti. 1938. Fascicolo speciale Esposizione Universale 1942. Architettura XII: 784-86.

Pansera, Anty. 1998. Metal tubing furniture in Italy. Designs and Manufactures between the two world wars. In Flexible Splendors. Tubular Furniture Metal. The Columbus Case. Edited by Anty Pansera. Milano: Electa, pp. 66-117.

Panseri, Carlo. 1936. Risposte di industriali all'articolo Battaglia da ingaggiare. Domus giugno: 48-49.

Papini, Roberto. 1936. Logica e architettura. Casabella 36: 1-5.

Persico, Edoardo. 1933. Gli architetti italiani. L'Italia letteraria 6 agosto. In Edoardo Persico. Scritti di Architettura 1927-1935. Edited by Giulia Veronesi. Firenze: Vallecchi, pp. 64-67.

Persico, Edoardo. 1934. Punto e a capo per l'architettura. Domus 83: 1-7.

Piacentini, Marcello. 1930. Architettura d'oggi. Roma: Cremonese.

Piacentini, Marcello. 1935. Metodi e caratteristiche. Architettura. La Città Universitaria di Roma fascicolo speciale XIV: 2-8.

Pica, Agnoldomenico. 1936. Nuova Architettura italiana. Milano: Hoepli.

Pica, Agnoldomenico. 1937. Il vetro e l'architettura. Rassegna di Architettura 6: 213-9.

Polin, Giacomo, and Ornella Selvafolta, eds. 1988. Mobili come aforismi. Trentacinque mobili del razionalismo italiano. Milano: Electa.

Ponti, Gio. 1928. La casa all'italiana. Domus 1: 7.

Ponti, Gio. 1930. L'ambiente moderno in Italia. Milano: Editoriale Domus.

Ponti, Gio. 1935. Battaglia da ingaggiare. Domus 96: 1.

Ponti, Gio. 1936. Qualità italiana contro qualità straniera. Domus 89: 17-24.

Ponti, Gio. 1949. L'opera di Pietro Chiesa. Domus 234: 32-49.

Poretti, Sergio. 1990. Progetti e costruzione dei Palazzi delle Poste di Roma 1933-1935. Roma: Edilstampa.

Poretti, Sergio. 1992. Marble facing in Italian Architecture from the 1930'. In Proceedings of the II Docomomo International Conference. Dessau: Bauhaus, pp. 191-94.

Poretti, Sergio, ed. 2005. Il restauro delle Poste di Libera. Roma: Gangemi Editore.

Poretti, Sergio. 2013. Italian Modernisms. Architecture and Construction in the Twentieth Century. Roma: Gangemi Editore.

Poretti, Sergio, and Rosalia Vittorini. 1996. The debate of 'autarchy' and the heterogeneity of Italian architecture. In Proceedings of the IV Docomomo International Conference. Bratislava: Sliac, pp. 172-76.

Rodogno, Davide. 2006. Fascism's European Empire. Italian Occupation during the Second World War. Cambridge: Cambridge University Press.

Romano, Giovanni. 1941. La casa di un architetto. Domus 163: 9-17.

Rossi, Catharine. 2015. Crafting Design in Italy: From Postwar to Postmodernism. Manchester: Manchester University Press.

Saggio, Antonino. 1984. L'opera di Giuseppe Pagano tra politica e architettura. Bari: Dedalo.

Saggio, Antonino. 1995. Giuseppe Terragni. Vita e opere. Roma: Laterza.

Sartoris, Alberto. 1932. Gli elementi dell'architettura funzionale. Milano: Hoepli. 
Sartoris, Alberto. 1941. Gli elementi dell'architettura funzionale. Milano: Hoepli.

Sartoris, Alberto. 1957. Encyclopédie de l'architecture nouvelle, Ordre et climat méditerranées, 2ème édition revue et augmentée. Milano: Hoepli.

Selvafolta, Ornella. 1980. Studi, progetti, modelli, oggetti del Razionalismo italiano. In Il disegno del mobile razionale in Italia 1928/1948. Edited by Gae Aulenti, Vittorio Gregotti, Maria Cristina Tonelli-Michail and Ornella Selvafolta. Special issue, Rassegna. Problemi di architettura dell'ambiente. 4, 17-88.

Sparke, Penny. 2008. The Modern Interior. London: Reaktion Books.

Spesso, Marco. 2017. L'architettura italiana nel movimento moderno 1926-1945. Padova: Libreriauniversitaria.it Edizioni. Tonelli-Michail, Maria Cristina. 1987. Il Design in Italia 1925/43. Roma: Editori Laterza.

Tropeano, Ruggero. 1998. The design of metal tubolar furniture in Europe. In Flexible Splendors. Tubular Furniture Metal. The Columbus Case. Edited by Anty Pansera. Milano: Electa, pp. 26-51.

Vellay, Marc, and Kenneth Frampton. 1984. Pierre Chareau: Architecte-meublier, 1883-1950. Paris: Éditions du Regard.

(C) 2019 by the author. Licensee MDPI, Basel, Switzerland. This article is an open access article distributed under the terms and conditions of the Creative Commons Attribution (CC BY) license (http:/ / creativecommons.org/licenses/by/4.0/). 